\title{
Specialised recreational fishers reject sanctuary zones and favour fisheries management ${ }^{*}$
}

\author{
Asha McNeilla, Julian Clifton ${ }^{\mathrm{a}}$, Euan S. Harvey ${ }^{\mathrm{b}}$.
}

${ }^{a}$ UWA School of Agriculture and Environment and the Oceans Institute, University of Western Australia, 35 Stirling Highway, Crawley, Perth, Western Australia 6009, Australia

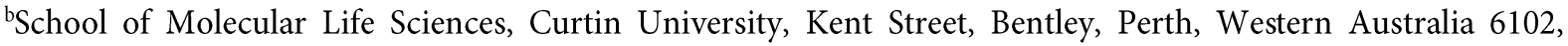
Australia

Corresponding author: asha.mcneill@research.uwa.edu.au, asha.mcneill@gmail.com

\section{HIGHLIGHTS}

- Recreational fishers attitudes vary with specialisation level and motivations

- Specialised fishers are most committed and highly value non-catch aspects of sport

- The most specialised fishers demonstrate highest support for fisheries management

- One in ten demonstrate strong opposition to sanctuary zones, but not other closures

- Explains how influential minority have a disproportional impact on policy

ABSTRACT Policy-makers are faced with the ongoing challenge of designing management interventions which conserve marine ecosystems while maintaining a sustainable level of resource user access. Recreational fishers are a key stakeholder group to consider as their activities can have significant impacts on fish populations. In some contexts, recreational fishers also represent a significant proportion of the public and can hold considerable influence on governing authorities. This issue is particularly pertinent for marine protected areas as significant opposition exists within some local communities, including recreational fishers, and community support is critical to achieving success. An online survey was employed across Western Australia to investigate recreational fishers' motivations and their attitudes towards fisheries management and different types of spatial closures, including marine protected areas. The results show the most specialised fishers demonstrate stronger support for traditional fisheries management compared to other groups, but stronger opposition to closed fishing zones specified as sanctuary zones. In comparison, no strong opposition is present for temporarily closed fishing zones or those protecting unique or fragile places. Our results suggest that rather than

${ }^{*}$ This is a post-print version of the follow article, licensed under CC-BY-NC-ND. Please cite as: McNeill, A., Clifton, J. \& Harvey, E.S. (2019) Specialised recreational fishers reject sanctuary zones and favour fisheries management Marine Policy, 107, 103592. 
spatial fishing closures, it is the designated purpose of sanctuary zones for precautionary management which some specialised fishers reject. Understanding patterns of support are vital for policy-makers to design and communicate policy which is seen as appropriate and legitimate amongst stakeholders, particularly to those specialised fishers who hold significant influence in fishing communities.

\section{Keywords}

Angling; attitudes; fishing regulations; marine protected areas; marine reserves; recreational fisheries management.

\section{Infographic summary}

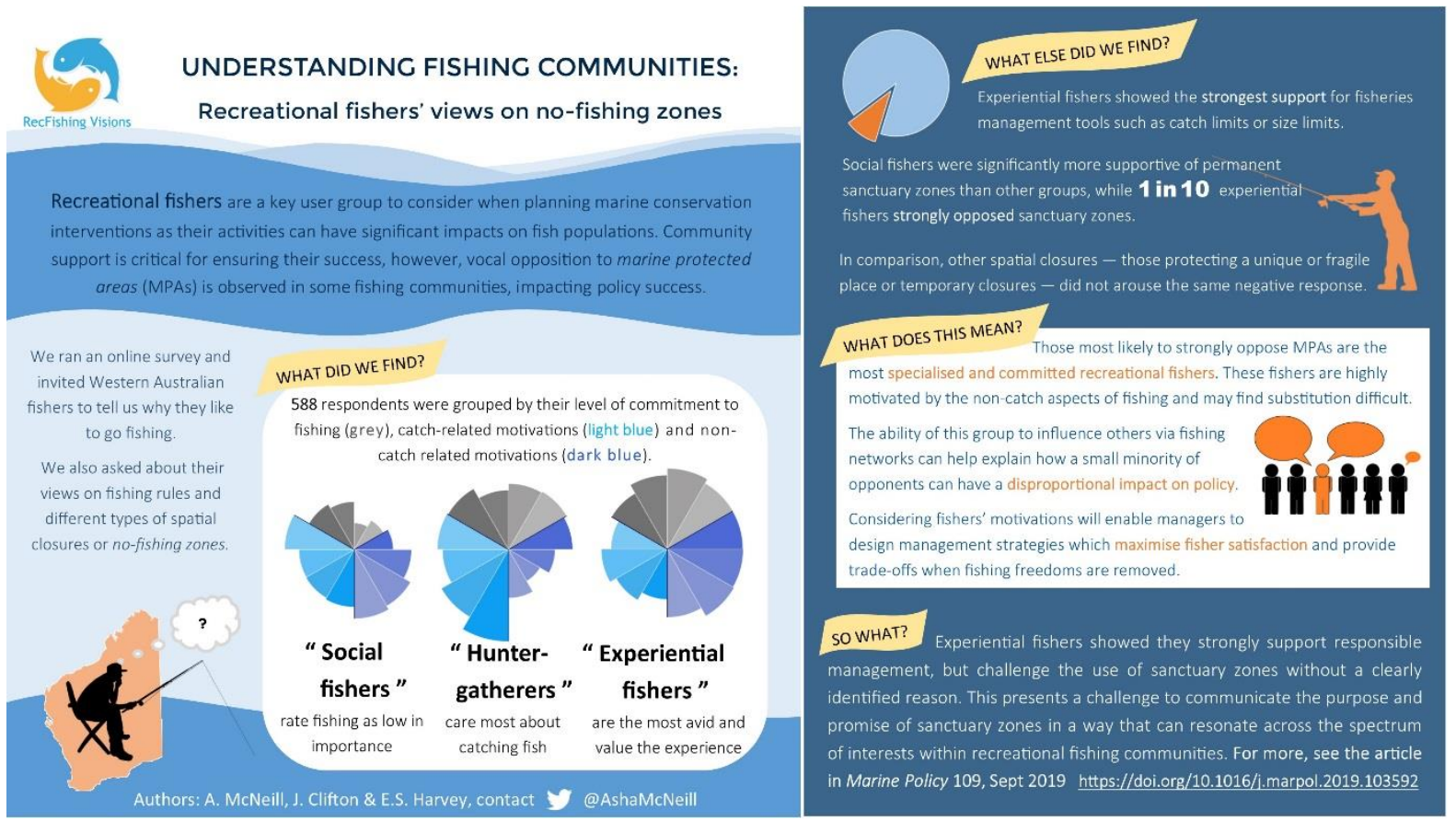




\section{INTRODUCTION}

Globally, marine ecosystems are under pressure from human impacts including climate change, coastal development, habitat destruction, introduced pests and diseases, pollution and fishing (Halpern et al., 2008). Marine protected areas (MPAs) are a spatial management tool designed to conserve biodiversity by mitigating the cumulative impacts of these threats and are often used in conjunction with more specific controls on fishing input and output. However, communities which rely on marine ecosystems for food, livelihoods and recreation may experience negative social, economic and cultural impacts following MPA designation (Mascia et al., 2010) leading to poor community support (Bennett \& Dearden, 2014b). This is significant because there is a strong linkage between the social and biological successes of interventions (Pollnac et al., 2001; Christie, 2004; Bennett \& Dearden, 2014b). Hence, the success of MPAs in meeting conservation goals depends to a large part on stakeholder acceptance and compliance (Hatcher et al., 2000; Viteri \& Chávez, 2007). Consequently, establishing, maintaining and improving community acceptance and support is integral for marine resource and conservation managers (Bennett, 2016).

Recreational fishing is an extremely popular global sport and leisure activity undertaken by roughly one in ten people across the industrialised world (Arlinghaus et al., 2015). Participation is associated with a wealth of benefits to individuals and communities including health (Griffiths et al., 2017), nutrition (Cooke et al., 2018), social (Freudenberg \& Arlinghaus, 2009), cultural (Palmer, 2004) and economic (Herfaut et al., 2013). The worldwide recreational catch has been estimated at $12 \%$ of the take for all fish (Cooke \& Cowx, 2004) representing a significant impact on marine ecosystems globally (Lewin et al., 2006). Yet to counter these possible consequences, recreational fishers also represent a unique opportunity for engagement as a conservation partner through their inherent interest in the fishery resources on which they depend (Granek et al., 2008).

The level of support for MPAs in recreational fishing communities is an area of high interest given their increasing designation in line with international commitments. Recreational fishers are from a variety of socioeconomic backgrounds and partake in the sport for a variety of motivations, which makes it difficult to ensure that MPAs are not perceived as unduly impacting such a diverse user group. Recreational specialisation is a useful conceptual framework to explore heterogeneity in recreational groups. Bryan (1977) defined specialisation as a progression of behaviour and attitudes from general interest and low involvement through to specialised interest and high involvement. This includes a behavioural dimension measured by frequency of participation, a cognitive dimension measured by 
skill and knowledge and an affective component measured by commitment to the activity (Scott \& Shafer, 2001). Accordingly, each specialisation level holds distinctive patterns of activity and orientations including equipment preference, type of experience sought, desired activity settings and preferences for regulation types. From a fishery management perspective, the theory predicts that increasing specialisation positively correlates with increasing support for fishing regulations (Bryan, 1977) due to a higher dependency on those resources to satisfy recreational aspirations (Ditton et al., 1992). However, there is evidence to suggest that this established relationship is non-existent or reversed in the context of MPAs (Salz \& Loomis, 2004, 2005; Voyer et al., 2014; Martin et al., 2016a).

In the state of Western Australia, recreational fishing participation is estimated at almost three times the global average, comprising $28 \%$ of the population (Henry \& Lyle, 2003). Additionally, the recreational fishing lobby is well organised and a vocal participant in community consultation. Similar to other locations globally (Chuenpagdee et al., 2013; McClenachan, 2013), some sections of fishing communities in Australia demonstrate significant opposition to MPAs (Voyer et al., 2015a; MeyerMcLean \& Nursey-Bray, 2017; Navarro et al., 2018) and have been successful in overturning MPA policy (Gladstone, 2014; Buxton \& Cochrane, 2015). Achieving a detailed understanding of recreational fishers' attitudes towards MPAs is therefore highly pertinent to facilitating effective marine conservation both in this context and at the international scale given the widespread participation in recreational fishing at the global level. We report the results of a survey of recreational fishers in Western Australia to highlight the importance of segmentation based on individual motivations and use this to explore differences in attitudes to fisheries management regulations and MPAs in particular. These enable conclusions to be drawn to better explain varying levels of support for regulations within fishing communities and assist the design, communication and implementation of policies which impact upon this stakeholder group.

\section{METHODS}

Across Western Australia, recreational fishers are largely regulated in their activities by two separate but complementary strategies: management of fish stocks by the Department of Primary Industries and Regional Development (hereafter DPIRD, previously known as the Department of Fisheries) and conservation of biodiversity by the Department of Biodiversity, Conservation and Attractions (hereafter DBCA, previously known as the Department of Parks and Wildlife). The DPIRD has implemented some small no-fishing zones as fish habitat protection areas, as well as some spatial fishing closures, to protect breeding fish stocks in some locations. Generally, the DPIRD does not 
implement closed fishing zones as a stock management strategy, instead employing a suite of fisheries management tools to maintain stocks (Penn \& Fletcher, 2010). The DBCA has management responsibility for the thirteen multiple-use MPAs, known as marine parks, within West Australian state waters implemented to conserve biodiversity (Figure 1). Within each marine park, a range of zone types dictate permitted activities within specific areas. These include general use zones where fishing regulations apply, zones where some fishing types are prohibited and no-take zones known as sanctuaries.

Recreational fishers state-wide were invited to participate in an online survey to collect information about their behaviour and attitudes. Online surveys are a cost-effective method that can be used to collect social data from targeted audiences, however, they also present drawbacks. The nature of convenience sampling online does not obtain a valid sample of the population and nonresponse bias cannot be estimated (Duda \& Nobile, 2010), therefore, cannot be considered representative. However, traditional survey methods also suffer challenges. Surveys conducted face to face may introduce interviewer bias and lack of willingness to disclose sensitive information (Bowling, 2005), particularly concerning a contentious topic. Compared to traditional methods, self-selected online sampling attracts participants with higher activity participation rates (Graefe et al., 2011), representing a community of fishers more likely to participate in public consultation (Sutton, 2006). Although observed participant characteristics may differ when utilising online surveys, mixed mode sampling indicates the attitudes captured are not significantly different across techniques (Graefe et al., 2011; Wallen et al., 2016). Therefore, this approach allowed useful insights into subpopulations of fishers and provided a sample of high importance to policy-makers.

The survey captured information on recreational fishers' demographics, avidity, motivations and opinions of management. Specialisation was estimated using four measures of avidity (Bryan, 1977; Salz et al., 2001). Variables included the participants number of years' experience fishing, the number of days participants spent fishing in the previous 12 months, self-rated ability (beginner, intermediate, advanced, expert) and self-rated importance of fishing as an activity (first, second, third most important or one of many outdoor activities) after Garlock and Lorenzen (2017). Motivation to fish was measured separately for catch and non-catch using a five-point Likert scale ranging from "not at all" to "extremely important”. Catch motivations were measured using 12 items across four constructs derived from Anderson et al. (2007) comprising the importance of catching something; catching many fish; catching large fish and keeping fish. Non-catch motivations were measured using fourteen items derived from 
Young et al. (2016b), including fishing companionship, sporting elements and environmental aspects. A full list of survey items is provided in Table 1 in the Supplementary Materials.

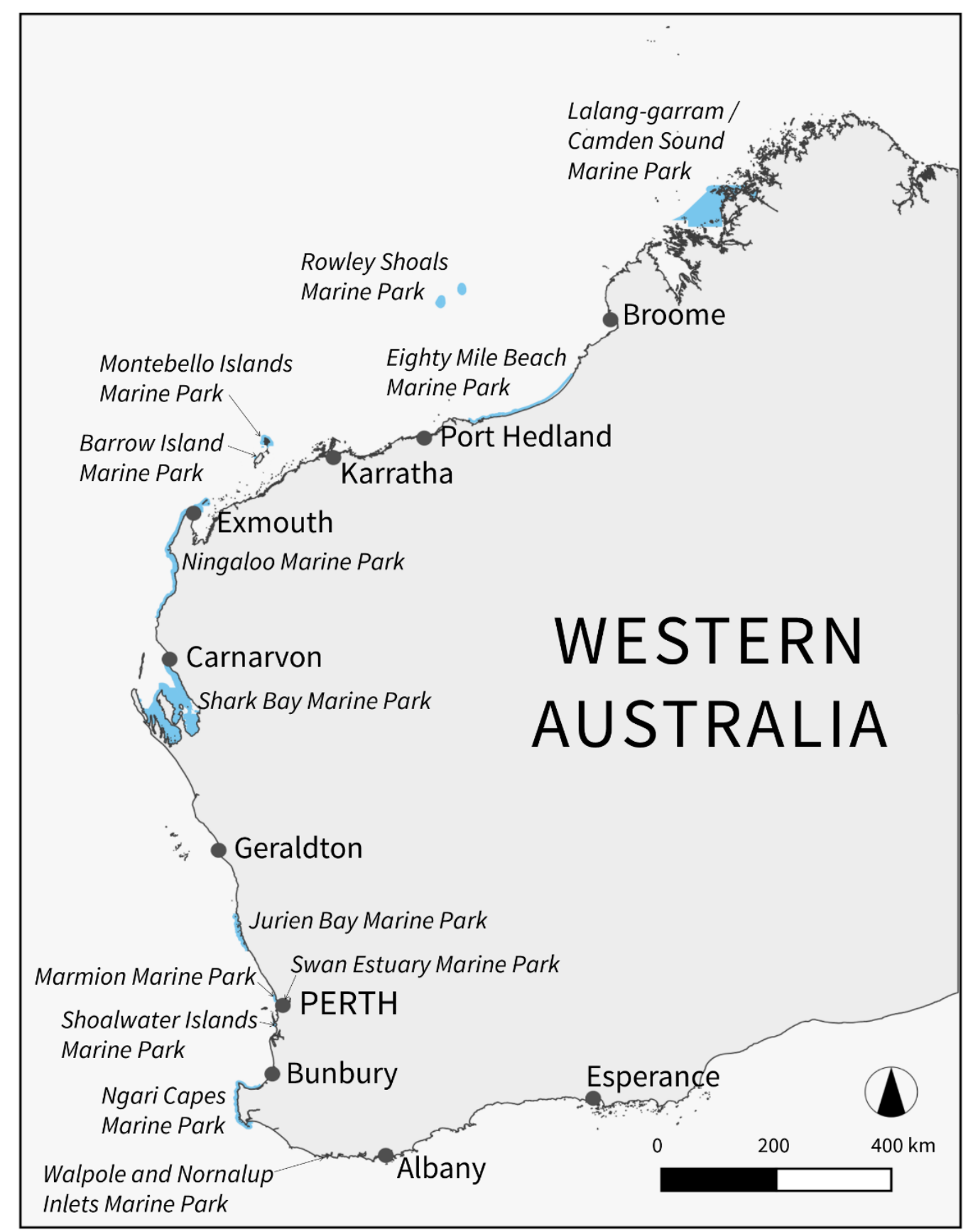

Figure 1. Map of the locations of thirteen multiple-use marine parks within West Australian state waters. 
Fishers' opinions were measured using three topics: support for West Australian regulations related to recreational fishing; views on fisheries management issues; and attitudes towards state government agencies with implementation responsibilities (for a full list of survey items see Table 2 in the Supplementary Materials). Support for regulations was measured for ten fisheries management and conservation tools in Western Australia, measured on a five-point Likert scale of "strongly oppose" to "strongly in favour" and "don't know". Seven commonly applied non-spatial fisheries management tools were tested, along with three spatial management strategies for different purposes; closed areas for a specific event, closed areas to protect a unique or fragile place and permanently closed areas known as sanctuary zones. Views on recreational fishing management were measured using twelve belief statements on a five-point Likert scale of strongly disagree to strongly agree. Topics included the need for regulation of fishing, the environmental threat of fishing, common arguments against and for MPAs in Australia (Gladstone, 2014; McNeill et al., 2018), including an equal number of positively and negatively worded statements. Attitudes to management agencies were measured for the DPIRD and DBCA. Participants were first required to answer a screening question to determine if fishers were aware of the two different departments. Attitudes to the departments were measured using eight author generated belief statements based on theories of justice (Daigle et al., 1996, Tyler, 1989). Items were the same for each department but adjusted to refer to the correct responsibilities. Items included an equal number of positively and negatively statements measured on a 5-point Likert scale of "strongly disagree" to "strongly agree" and "don't know". Responses of "don't know" were recoded as missing data and excluded.

The survey was piloted to ensure items were clear and appropriate for all skill levels. The survey was created using Qualtrics software (Qualtrics, Provo, UT) and accessible via a website interface which provided participant information (www.recfishingvisions.com). The link was distributed via social media and paid advertising targeting both fishing and non-fishing interests. The link was included in fishing clubs, sailing clubs, regional community groups and other newsletters upon approach by the authors. The survey was also distributed via a paper flyer placed in tackle shops. Voluntary entry into a prize draw was offered for successful completion, and incomplete surveys were discarded. Data were collected between December 2016 and July 2017 and participants' prior and informed consent was obtained. The research was approved by the University of Western Australia Human Ethics committee (RA/4/1/7517). 


\section{1 DATA ANALYSIS}

\section{Fisher segmentation}

Cluster analysis is an exploratory method used to partition data into clusters of objects similar to each other (Kaufman \& Rousseeuw, 2009). This technique was employed to segment recreational fishers into groups based on their avidity and motivational profiles. Before clustering, negatively worded variables were recoded so all variables positively correlate with specialisation or motivational factors. Data dimensionality amongst motivational factors was reduced by performing principal components factor analysis with varimax rotation (SPSS version 24) on twelve catch-related and fourteen non-catch related motivations. Four factors were extracted from catch motivations based on aspects identified previously (Anderson et al., 2007) namely catching something, catching many fish, catching large fish and keeping fish. Four factors were extracted from non-catch related motivations using eigenvalues greater than one, resulting in factors relating to fishing for sport, exploring the outdoors, fishing for relaxation and social aspects. In line with Dolnicar and Grün (2008) and Hyman et al. (2017), the variables with the highest $\mathrm{r}^{2}$ value were chosen to represent each principal component resulting in eight motivational variables. The four catch-related motivational factors were 'a fishing trip can be successful even if no fish are caught', 'A successful fishing trip is one in which many fish are caught', 'I would rather catch one or two big fish than ten smaller fish' and 'I usually eat the fish I catch'. The four noncatch related motivational factors were; 'for the challenge of the sport of catching fish', 'to experience the natural environment,' 'to escape from everyday life, work or the city' and 'for the social experiences with friends'.

The motivational variables were used as input for cluster analysis together with the four avidity variables. All variables were checked for correlation and transformed to $\mathrm{z}$ scores to ensure equal weighting (Milligan \& Cooper, 1988). A two-stage cluster analysis was performed to segment survey respondents into distinct sub-groups (Punj \& Stewart, 1983). Initially, hierarchical cluster analysis based on Ward's method and squared Euclidean distance was used to determine cluster starting points and optimum number of clusters (SPSS version 24). Clusters were validated using the L test (Salvador \& Chan, 2004) and the NbClust function in R Version 3.4.2 (Charrad et al., 2014). Sub-group means from hierarchical clustering analysis for the twelve variables were used as input for non-hierarchical k-means clustering to enhance cluster allocation accuracy (Milligan, 1980; Clatworthy et al., 2007). Clusters were validated using canonical analysis of principal coordinates (Anderson \& Willis, 2003) in the 
PERMANOVA+ add on to PRIMER (Anderson et al., 2008) and discriminant analysis (SPSS version 24).

\section{Comparison of recreational fishing groups}

Due to the ordinal nature of the data, the non-parametric Kruskal-Wallis test was used to examine whether support for management tools and attitudes to recreational fishing management were different between fisher groups. When a significant difference was detected at $\mathrm{p}<0.05$, post-hoc pairwise comparisons were performed using the Dunn-Bonferroni approach to counter the effects of multiple testing (SPSS version 24 ). The tests were repeated at $\mathrm{p}<0.01$ to highlight those differences which satisfy the more stringent probability test.

\section{Comparison of closed fishing area types}

To investigate if the stated purpose of closed fishing areas influenced recreational fishers' opinions, we ran an additional non-parametric test to compare closed areas specified as a sanctuary zone with closed areas for a specific event such as fish spawning, and closed areas used to protect unique and fragile places. Due to the non-symmetrical distribution of the survey responses, a paired-samples sign test was used to compare the number of positive and negative differences in individuals' support for the three different closed area types within fisher groups (Siegel \& Castellan, 1988).

\section{RESULTS}

While the DPIRD conducts a comprehensive state-wide survey of recreational boat fishing every two years which measures fisher avidity, this sample does not include shore fishers (Ryan et al., 2015). Therefore, a direct comparison between the avidity of the survey sample and the state-wide fishing population is not possible. However, some observations can be made. A total of 588 completed responses were received, with $15.1 \%$ of participants female, similar to the most recent state-wide survey from 2013-14 (15.0\%, Ryan et al., 2015). Participants were on average younger, with a higher representation of the age group 18-29 years (here 23.5\% aged 18-29 years compared to $14.0 \%$ aged 1529 years). On average, they fished 44.23 days in the previous 12 months (median $=30$ days), similar to the recreational fishing internet survey results of Magee et al. (2018) on the east coast of Australia. However, Ryan et al. (2015) found only $35-37 \%$ of respondents fished more than 15 days, indicating our sample was significantly more avid than the wider West Australian boat fishing population. 


\subsection{FISHER SEGMENTATION}

A total of 561 valid surveys with responses to the eight selected motivational variables and four avidity variables were used for the clustering analysis. The majority rule suggested either the two or three cluster solution were acceptable, however, inspection of the dendrogram and cluster means led to the three cluster solution being chosen as appropriate. Validation of the cluster solution resulted in $95.5 \%$ of cases correctly classified in leave-one-out allocations of observations to groups using canonical analysis of principal coordinates. Additionally, $94.1 \%$ of original and $92.3 \%$ of cross-validated grouped cases were correctly classified using discriminant analysis. The three groups were examined for patterns and designated according to their avidity and motivational profiles compared to the group average, namely "Experiential fishers", "Hunter-gatherers" and "Social fishers" (Figure 2).

Participants classified as social fishers $(\mathrm{n}=137,24 \%)$ were the least specialised of the groups, rating their skill level the lowest. Social fishers are happy to substitute fishing for other activities, demonstrated by the low importance of the sport compared to the other outdoor activities. Being in the natural environment and being with friends are important motivations, and they are likely to keep and consume their catch. Hunter-gatherers $(n=156,28 \%)$ were the second most specialised sample group and are motivated by the challenge of the sport of fishing, however other non-catch motivations are less

(a) Social fishers

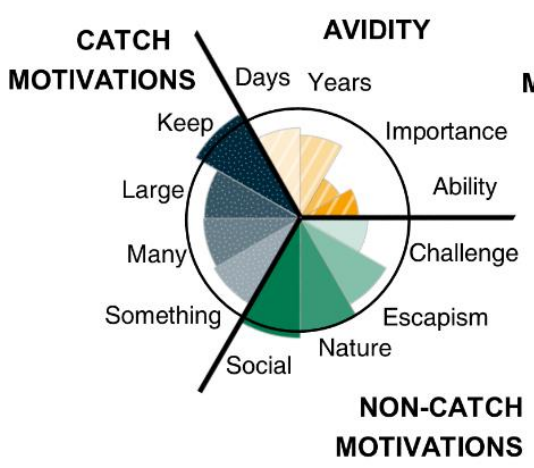

(b) Hunter-gatherers

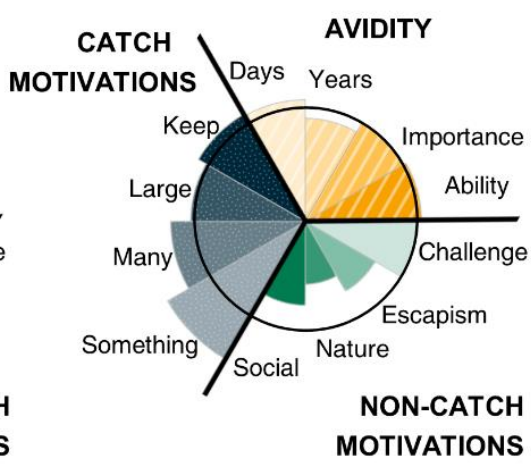

(c) Experiential fishers

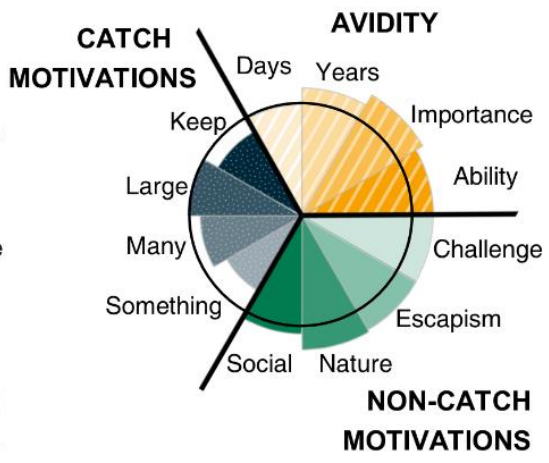

Figure 2. Summary of the three resulting recreational fisher groups when classified by avidity, catch and non-catch motivations, (a) Social fishers, (b) Hunter-gatherers and (c) Experiential fishers. The size of each pie slice indicates the mean transformed score for each classification variable, central circle indicates an average of zero. 
important. These fishers are catch focused and find it particularly motivating to catch something during a fishing trip to obtain satisfaction. Experiential fishers $(\mathrm{n}=268,48 \%)$ rated above average for all noncatch motivations, particularly the challenge aspects, indicating these individuals are highly motivated to participate for the total experience of the sport. Their catch related motivations are low, however, they are motivated by the experience of catching large fish. They were the most specialised group, demonstrated by the avidity variables.

\subsection{COMPARISON OF RECREATIONAL FISHING GROUPS}

Only topics which demonstrated significant differences between fisher groups are reported. Significant differences were observed for six types of regulations (Figure 3). Experiential fishers had significantly higher support for catch regulations over hunter-gatherers and social fishers including minimum sizes $(\mathrm{p}<0.05)$, maximum sizes and slot limits $(\mathrm{p}<0.05)$, catch limits $(\mathrm{p}<0.01)$ and possession limits $(\mathrm{p}<0.01)$. Experiential fishers also had higher levels of support for gear restrictions, while social fishers demonstrated the lowest support (pairwise test adjusted $\mathrm{p}<0.05$ ). Conversely, experiential fishers showed the highest level of opposition to closed areas known as sanctuary zones, with $9.9 \%$ of the group expressing strong opposition, along with $4.8 \%$ of hunter-gatherers. Social fishers demonstrated significantly more support for sanctuary zones than both experiential fishers (pairwise adj. $\mathrm{p}<0.01$ ) and hunter-gatherers (pairwise adj. $\mathrm{p}<0.05$ ).

Compared to social fishers, experiential fishers held considerably more critical attitudes towards MPAs (Figure 4). They were significantly more likely to agree MPAs can cause damage due to shifting fishing effort (pairwise adj. $\mathrm{p}<0.01$ ) and believed there is no evidence to justify large no-fishing zones (pairwise adj. $\mathrm{p}<0.01$ ). Experiential fishers also perceived the impact of recreational fishing on the environment to be lower compared to social fishers. They were more likely to agree recreational fishing is not a threat (pairwise adj. $\mathrm{p}<0.01$ ) and recreational fishers are unfairly portrayed (pairwise adj. $\mathrm{p}<0.01)$. Experiential fishers were also less likely than social fishers to believe closed fishing zones can protect important sites such as fish nurseries (pairwise adj. $\mathrm{p}<0.05$ ) and are a good safeguard to conserve future marine ecosystems (pairwise adj. $\mathrm{p}<0.05$ ), and more likely to agree MPAs won't protect fish due to the open nature of protection zones (pairwise adj. $\mathrm{p}<0.05$ ). 


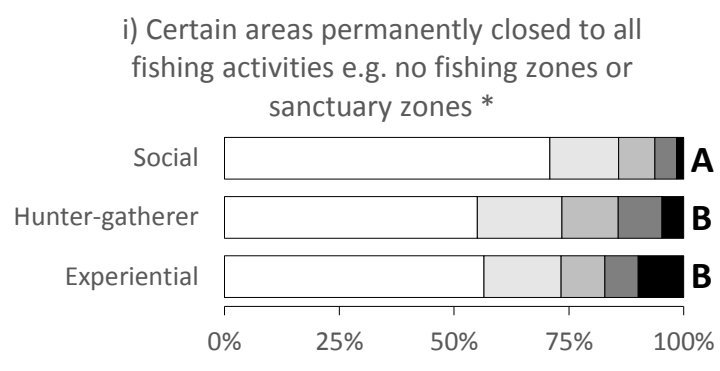

iii) Size limits - minimum sizes

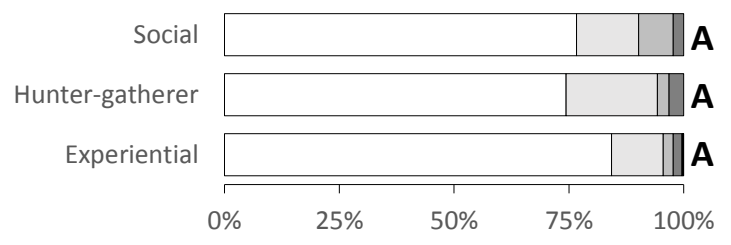

v) Possession limits *

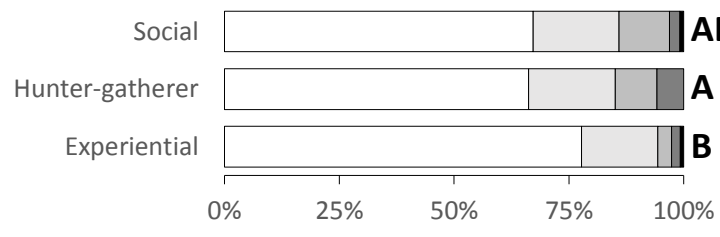

$\square$ Strongly in favour $\square$ Somewhat in favour ii) Gear restrictions e.g. number of hooks or use of spear guns

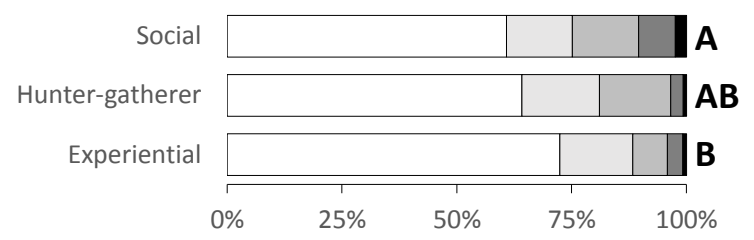

iv) Size limits - maximum sizes and slot limits

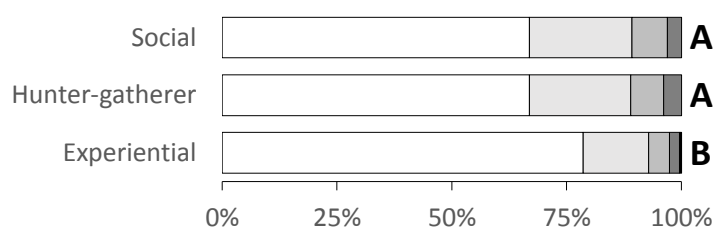

vi) Catch limits e.g. bag and boat limits *

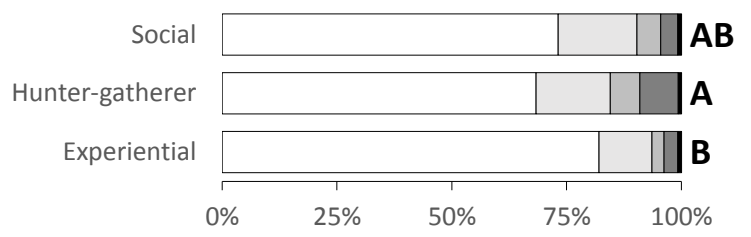

Neutral

Strongly oppose

Figure 3. Support for recreational fishing regulations which differ amongst the three fisher groups when tested using the Kruskal-Wallace test at $\mathrm{p}=0.05$. Bars represent the proportion of each group responding to statements on a 5 point ordinal scale from "strongly in favour" to "strongly oppose". Statements also significantly different when tested at $\mathrm{p}=$ 0.01 are indicated using ${ }^{*}$ ). Results of pairwise tests between fisher groups are indicated using different letters, (A) or (B). Groups labelled with the same letter are not significantly different when tested in pairs at $\mathrm{p}=0.05$ using the Bonferroni correction. Thus, the results for statement (iii) demonstrate no significant difference exists between any pair of groups when applying the corrected significance level.

Hunter-gatherer attitudes were generally similar to experiential fishers. They were significantly more likely than social fishers to disagree closed areas are a good safeguard (pairwise adj. $\mathrm{p}<0.05$ ), closed areas protect important sites (pairwise adj. $\mathrm{p}<0.05$ ) and recreational fishing is a threat (pairwise adj. $\mathrm{p}<0.01$ ). They were significantly more likely than social fishers to believe there is no evidence to justify large no-fishing zones (pairwise adj. $\mathrm{p}<0.01$ ), although comparatively less likely than experiential fishers (pairwise adj. $\mathrm{p}<0.05$ ). Hunter-gatherers were the group least willing to change their fishing behaviour to support fishing in the future, significantly less than social fishers (pairwise adj. $\mathrm{p}<0.05)$. However, for the statement "Recfishers are unfairly portrayed by conservationists as damaging the marine environment", hunter-gatherers had a significantly lower level of agreement than experiential fishers (pairwise adj. $\mathrm{p}<0.01$ ), similar to that of social fishers (no significant difference detected, pairwise adj. $\mathrm{p}>0.05)$. 


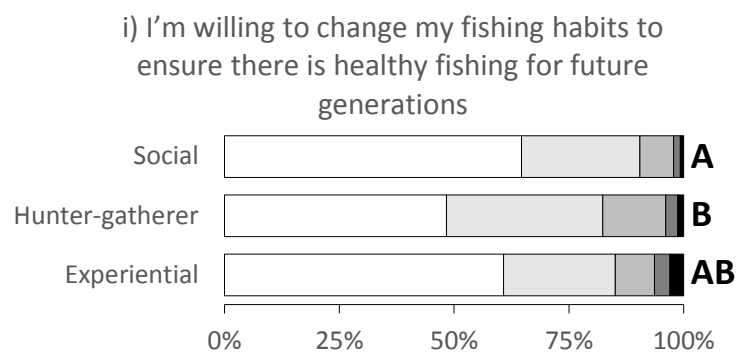

iii) Closing some areas to fishing permanently is a good safeguard to help conserve marine ecosystems in the future

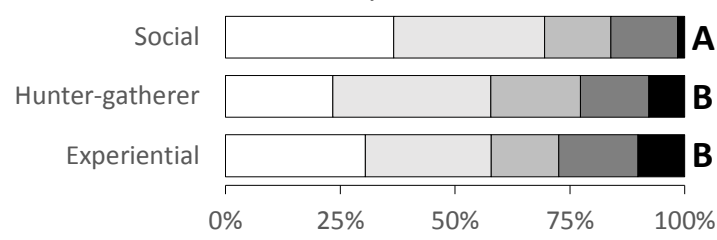

v) The combined impact of thousands of recfishers can result in damage to the marine environment

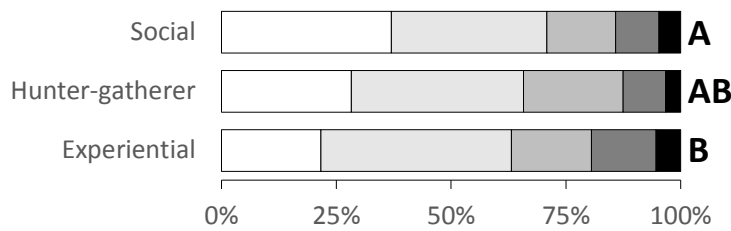

vii) Closing some areas to fishing permanently can help protect important areas like fish nurseries *

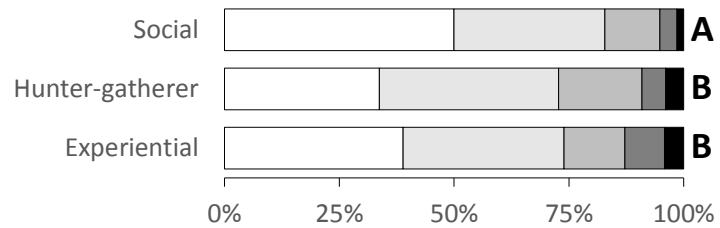

ii) Closing some areas to fishing permanently can damage other open areas due to crowding of fishing pressure *

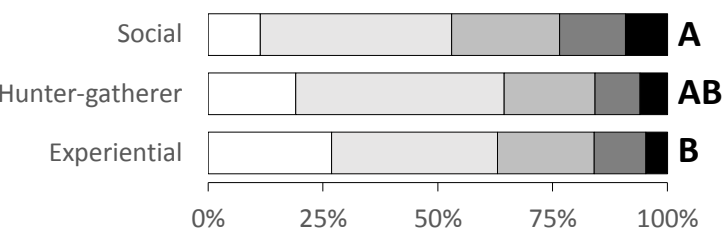

iv) There is no scientific evidence to justify locking out recreational fishers from large areas of our seas *

Social

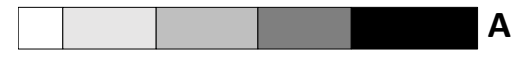

Hunter-gatherer

Experiential

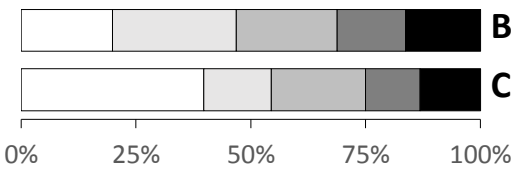

vi) Recfishers are unfairly portrayed by conservationists as damaging the marine environment *

Social

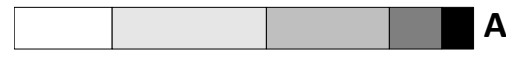

Hunter-gatherer

Experiential

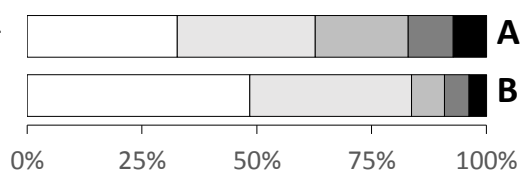

viii) Recreational fishing is not a threat to healthy marine ecosystems *

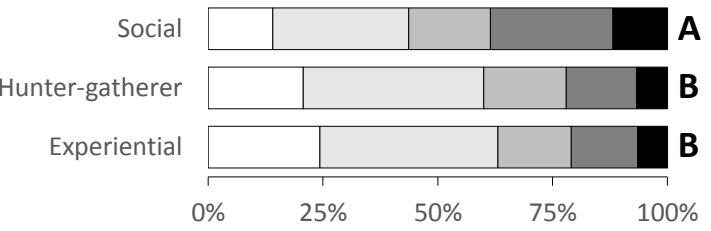

ix) Areas closed to fishing won't protect fish because there are no fences around protected areas to keep them inside

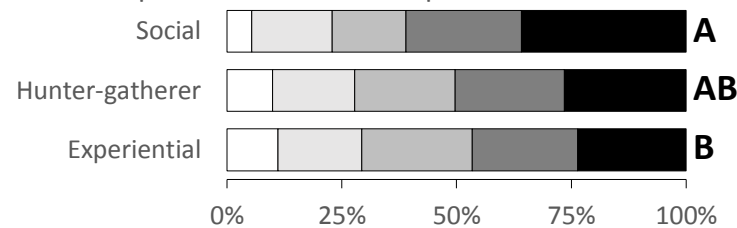

$\square$ Strongly agree $\square$ Somewhat agree $\square$ Neither agree nor disagree $\square$ Somewhat disagree $\square$ Strongly disagree

Figure 4. Views on recreational fishing which differ amongst the three fisher groups when tested using the KruskalWallace test at $\mathrm{p}=0.05$. Bars represent the proportion of each group responding to statements on a 5 point ordinal scale from "strongly agree" to "strongly disagree". Statements also significantly different when tested at $\mathrm{p}=0.01$ are indicated using $\left({ }^{*}\right.$ ). Results of pairwise tests between fisher groups are indicated using different letters; (A), (B) or (C). Groups labelled with the same letter are not significantly different when tested in pairs at $\mathrm{p}=0.05$ using the Bonferroni correction. 
There were minimal differences between fishing groups when assessing their attitudes towards the DPIRD with only two of the statements resulting in significant differences (Figure 5). In both cases, hunter-gatherers were significantly more negative about the DPIRD; firstly about the ability of recreational fishers to influence fishing policy (compared to social fishers, pairwise adj. $\mathrm{p}<0.05$ ) and secondly about the equity of restrictions between sectors (compared to experiential fishers, pairwise adj. $\mathrm{p}<0.05)$. However, there were significant differences between fisher groups in their responses to the majority of the attitudinal statements related to the DBCA, the agency responsible for implementing marine parks in WA including sanctuary zones. Generally, the experiential fishers were significantly more critical of the DBCA than social fishers, followed by hunter-gatherers (Figure 5). Experiential fishers were more likely to disagree with social fishers they receive fair and reasonable treatment (pairwise adj. $\mathrm{p}<0.01$ ), the DBCA respects their right to fish (pairwise adj. $\mathrm{p}<0.05$ ) and fishers have influence over marine park policy (pairwise adj. p<0.05). The majority of experiential fishers $(52.7 \%)$ either "strongly agree" or "somewhat agree" with the statement "marine parks unfairly impact recreational fishing while not protecting from other threats to the environment", significantly more than both hunter-gatherers (pairwise adj. $\mathrm{p}<0.05$ ) or social fishers (pairwise adj. $\mathrm{p}<0.01$ ). Hunter-gatherers and experiential fishers were more critical than social fishers about the DBCA's objectivity $(\mathrm{p}<0.05)$, with $17.5 \%$ experiential fishers strongly disagreeing they make unbiased decisions, along with $17.2 \%$ of hunter-gatherers, compared to $6.2 \%$ of social fishers. Social fishers were more likely to agree "recreational fishers have been given the opportunity to have their say" compared to both other groups $(\mathrm{p}<0.05)$.

\subsection{COMPARISON OF CLOSED FISHING AREA TYPES}

The results of the sign test analyses indicated that recreational fishers in all three groups' demonstrate significantly lower support for sanctuary zone closed areas compared to specific event area closures or unique or fragile place closures. For experiential fishers, $34.5 \%$ had reduced support for sanctuary zones compared to closed areas to protect unique or fragile places, while $1.6 \%$ had increased support $(\mathrm{p}<0.01)$, and $33.2 \%$ had reduced support compared to specific event closures while $3.5 \%$ had increased support $(\mathrm{p}<0.01)$. A total of $32.1 \%$ hunter-gatherers had reduced support for sanctuary zones compared to unique or fragile closed areas while 3.6\% had increased support $(\mathrm{p}<0.01)$, and $29.6 \%$ had reduced support compared to specific event closures and $4.2 \%$ had increased support $(\mathrm{p}<0.01)$. For social fishers, $19.7 \%$ had reduced support for sanctuary zones compared to unique or fragile closed areas while $3.1 \%$ had increased support $(\mathrm{p}<0.01$ ), and $20.6 \%$ had reduced support compared to specific event 
closures and $7.1 \%$ had increased support $(\mathrm{p}<0.01)$. None of the groups demonstrated significant differences in support for unique or fragile area closures compared to specific event area closures $(\mathrm{p}>0.05)$.

\section{Attitudinal statements about the DPIRD}

i) The input of recfishers has no influence on WA fishing policy decisions

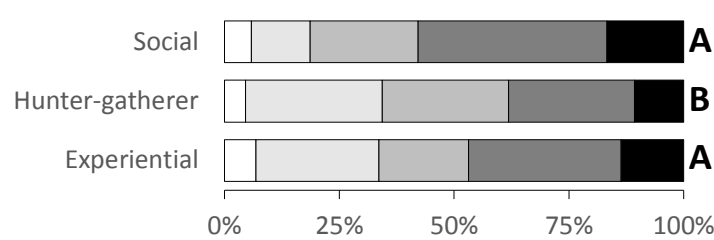

ii) The burden of fishing restrictions are equitably felt by commercial and

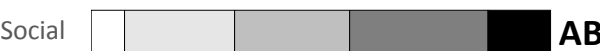

Hunter-gatherer

Experiential

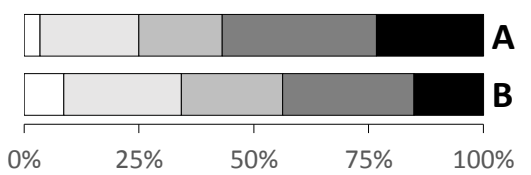

Attitudinal statements about the DBCA, previously known as DPaW

iii) The input of recfishers has no influence on WA Marine Parks policy decisions

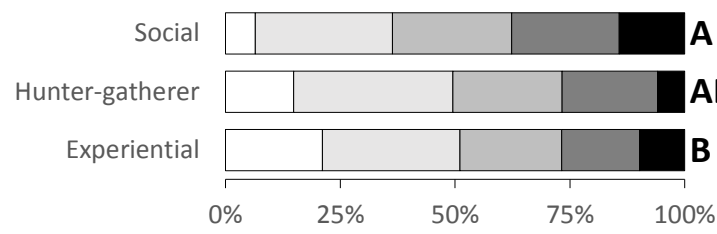

v) Marine Parks unfairly impact recfishing while not protecting from other threats to the environment $*$

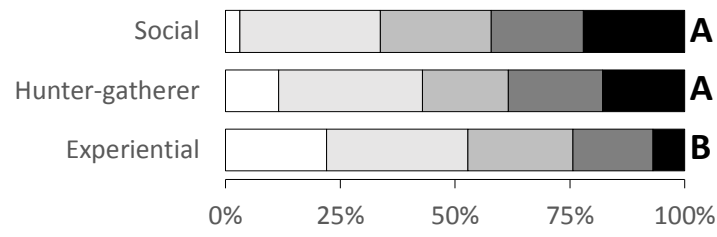

vii) DPaW don't treat recfishers in a fair and reasonable way *

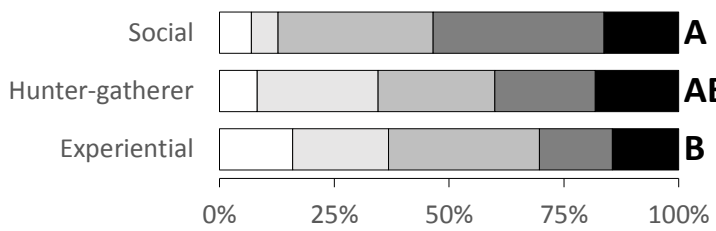

iv) DPaW shows respect for recfishers right to fish

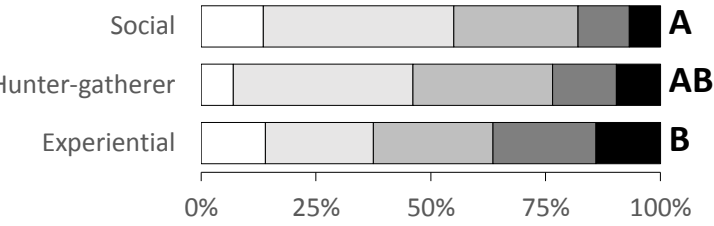

vi) DPaW makes unbiased policy decisions based on fact

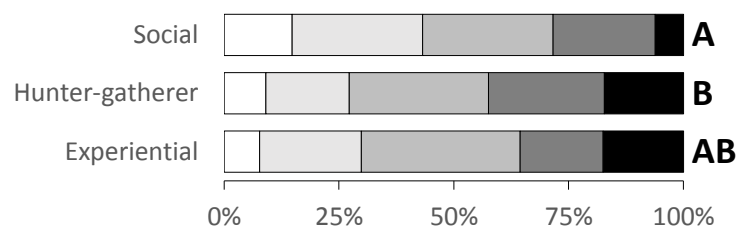

viii) Recfishers have been given the opportunity to have their say on Marine Parks in WA

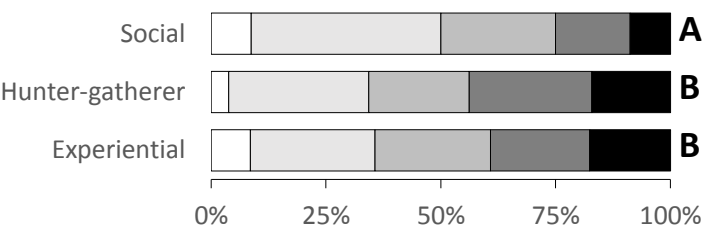

$\square$ Strongly agree $\square$ Somewhat agree $\square$ Neither agree nor disagree $\square$ Somewhat disagree $\square$ Strongly disagree

Figure 5. Attitudes to management authorities which differ among fisher groups when tested using the Kruskal-Wallace test at $\mathrm{p}=0.05$. Bars represent the proportion of each group responding to statements on a 5 point ordinal scale from "strongly agree" to "strongly disagree". Statements also significantly different when tested at $\mathrm{p}=0.01$ are indicated using $\left.{ }^{*}\right)$. Pairwise differences between fisher groups are indicated using different letters, (A) or (B). Groups labelled with the same letter are not significantly different at $\mathrm{p}=0.05 \mathrm{using}$ the Bonferroni correction. 


\section{DISCUSSION}

This research utilised a segmentation approach to reveal patterns of attitudes to recreational fishing management based on fishers' avidity and motivations. The characteristics of the three groups identified by this study align well with the results of other similar analyses based on the spectrum of specialisation (Bryan, 1977; Kyle et al., 2007; Magee et al., 2018). While categorisation of recreational fishers may disguise the complexity of an individual's circumstances, experiences and views, segmentation of recreational fishing participation provides valuable insights into the patterns of participation and their associated attitudes to management. While avidity and overall support for management are high, the three fisher groups hold significantly different views towards some aspects of recreational fishing management which may be linked with their avidity and motivational profiles.

The results for traditional fisheries management tools are consistent with the theory of recreational specialisation, where support for restrictions increases with specialisation (Bryan, 1977). However, the results clearly demonstrate the reverse relationship exists for permanent sanctuary zones. The strongest opposition is most present in experiential fishers, followed by hunter-gathers, in line with increasing specialisation. Whilst other research has indicated this phenomenon (Salz \& Loomis, 2004, 2005), this is the first time different types of closed areas have been investigated, demonstrating support differs depending on the purpose of the closed fishing area. There is no difference between the three fisher groups in their support for closed areas to protect unique or fragile places and closed areas for specific events, and strong opposition to these types of closed areas was negligible. All groups preferred these closures over permanent sanctuaries. In line with decreasing support for sanctuaries, specialised fishers also exhibited more critical views of MPAs as a management tool. The motivational profiles of each of the fisher groups can elucidate why these patterns may exist and will be discussed in greater detail below.

This research reveals a relatively high proportion of experiential fishers demonstrate a strong opposition to sanctuary zones compared to other fisher types. However, these fishers hold the highest level of support for restrictions on gear use and most catch related fisheries management restrictions. In comparison, hunter-gatherers and social fishers exhibit a lower level of support for these restrictions although social fishers hold significantly stronger support for sanctuary zones. These differences could, in part, be explained by differing feelings of psychological reactance (Brehm, 1966) between fisher groups based on how different management tools constrain their sources of satisfaction from fishing. Reactance occurs in response to threats such as regulations to curb behavioural freedoms, characterised 
by feelings of anger and counterarguments against threats (Rains, 2013). Regulations restrict different aspects of fishing behaviour, therefore stronger reactance may occur in fishers when a regulatory tool imposes restrictions on the aspect of fishing they value highest. Sanctuary zones represent a method which prohibits the ability of fishers to fish in certain locations or settings. Therefore, sanctuaries limit experiential fishers' enjoyment by restricting the number of available fishing experiences from which they can obtain their satisfaction, which is at the heart of their motivations. In comparison, traditional fisheries management regulations instead modify catch behaviour. These restrictions are unlikely to impact on satisfaction for experiential fishers since their consumptive orientation is low. On the other hand, social fishers and hunter-gatherers place more importance on keeping fish, therefore, reactance is stronger in those groups to catch restrictions.

The strength of reactance to restrictions depends on the characteristics of the individual and their perception of the threat (Brehm \& Brehm, 1981). These characteristics include the importance of the freedom to an individual, their freedom to choose and implied future threats to that freedom. Previous research demonstrates the most specialised fishers, in this case, experiential fishers, are more attached to fishing at specific sites and settings and are less able to substitute these (Bryan, 1977; Oh et al., 2013). Therefore, experiential fishers may place a higher importance on continuing to fish in areas targeted for sanctuary zones. Residual spatial planning exercises often result in sanctuary placement in areas of lowest use to minimise impacts on stakeholders overall (Devillers et al., 2014). However, in practice, this concentrates impacts on fishers willing to travel to further regions for unique or challenging experiences (Voyer et al., 2014), such as those preferred by experiential fishers. Reactance is also stronger when threats to future freedoms are present. With some organisations advocating up to $30 \%$ sanctuary zone coverage globally (IUCN, 2016), fear of future park expansion may be stronger in experiential fishers due to their higher level of dependency on fishing, unlike social fishers who are more willing to substitute other recreational activities for fishing (Sutton \& Oh, 2015).

However, the theory of psychological reactance does not explain the difference in support levels for closed fishing areas of different purposes. Amongst all three fishing groups, there is significantly less opposition to closed areas when they are specifically designed to protect an event, such as fish spawning aggregations, or a unique or fragile place. This demonstrates that it is the perceived purpose of permanent sanctuary zones which is the source of strongest opposition, not the regulation type. It may be when closed fishing areas are based around a physical attribute, the purpose of protection is clear. Potential risks can be easily identified and understood by recreational fishers, limiting opposition because the benefit can be observed. When sanctuary zones are established to meet 
international targets of protection $(\mathrm{CBD}, 2010)$ using the principals of comprehensive, adequate and representative protection, closed fishing zones may not appear to be unique or fragile and specific future threats need not be identified. As a result, support for closed fishing areas may be lower from some fishers because there is no direct or observable link between fishing activity and damage to a specific area and the closure may seem unnecessary. Threat justification is a powerful determinant of reactance magnitude (Brehm, 1966), which could explain higher reactance to closed areas which lack a clear justification and resulting in differing levels of support for permanent sanctuary zones in fishers.

These results indicate a significant proportion of experiential fishers, and to a lesser extent the hunter-gatherers, reject the notion permanent sanctuary zones will conserve marine ecosystems in the future unless stationed around a specific threatened area. Previous research demonstrates that as specialisation increases, fishers acquire greater knowledge and skills due to their intimate involvement in the marine environment needed to master the sport (Scott \& Shafer, 2001). This suggests as fishers' understanding increases they begin to think more critically about the use and purpose of sanctuary zones. Yet these fishers are more likely to view the issue as a question of stock management due to their acquired specialised "knowledge about fish" (Voyer et al., 2014), and as a result may overemphasise the benefits to stocks over their primary goals of conserving intact ecosystems (Jones, 2007). Sanctuary zones are regularly supported by arguments in the Australian media that establishment will increase fish stocks or improve fishing experiences (Voyer et al., 2013) due to the extensive evidence globally that this is the case (Lester et al., 2009). However, this common perception in some local stakeholders (McNeill et al., 2018) is in direct opposition to their intended purpose of use in Western Australia for biodiversity conservation. It is also in conflict with evidence from the DPIRD disputing the use of sanctuary zones to manage fish stocks (Penn \& Fletcher, 2010) and other fisheries scholars worldwide (Hilborn et al., 2004; Kearney et al., 2012) in areas where traditional fisheries management is adequate. Therefore, when sanctuary zones are either assumed to be or promoted as a tool to manage fish stocks, knowledgeable fishers such as those in the experiential group reject them as inappropriate management.

The results also indicate that as fisher specialisation increases, negative attitudes towards the management authority responsible for marine parks in WA also increase. In comparison, attitudes towards the DPIRD do not differ considerably between groups. Perceived legitimacy and trust in the DBCA is lowest in experiential fishers, correlating with the high number of opponents to permanent sanctuary zones. While the connection between poor attitudes towards the DBCA and low support for sanctuary zones is clear, it is somewhat difficult to elucidate the directional driver of this relationship. Trust in management has been shown to be a key driver of stakeholder support for MPAs (Turner et 
al., 2016; Dehens \& Fanning, 2018) and satisfaction with the outcome of the MPA establishment process (Ordoñez-Gauger et al., 2018). Equally, hostility towards the source of the threat is recognised as an outcome of reactance to restrictions of freedom (Brehm \& Brehm, 1981). To compound the situation, trust in the source of information has been identified as a factor in whether people believe or trust information itself (Gilmour et al., 2015). Therefore, when trust is lacking in the management agency, information provided to justify sanctuary zones will also not be trusted, as evidenced in the patterns of attitudinal responses from experiential fishers.

\subsection{IMPLICATIONS FOR RECREATIONAL FISHING MANAGEMENT}

The results of this research can assist MPA planners and managers to better understand the conflict and opposition that exists within sections of recreational fishing communities and inform the management of recreational fisheries more broadly. Particularly in Australia, the recreational fishing sector is a large, well organised and powerful stakeholder group which holds significant sway as a large block of the voting public. Therefore, the support of the sector for various management decisions is vital for ensuring the long-term effectiveness of policy which affects this group. While it is commonly observed that overall support for sanctuary zones is high amongst recreational fishers in Australia (reviewed in Sheridan, 2016; Navarro et al., 2018), this study demonstrates different types of fishers have varying levels of support for management restrictions, and higher levels of opposition exist within subpopulations. Significantly, it is the most committed recreational fishers who demonstrate the greatest opposition, with one in ten experiential fishers showing strong opposition to sanctuary zones. This has considerable implications for knowledge exchange and influence within recreational fishing communities.

Due to their higher importance of fishing in their lives, experiential fishers are most likely to be involved in social settings centred around fishing, part of fishing networks and contribute to fishing discussions (Sutton, 2003). There is also evidence committed fishers are more likely to take part in community consultation (Sutton, 2006) and may be more likely to hold positions of influence within the fishing sector through representative positions. This could lead to a small, but vocal number of opponents having an influential voice in public discussions and consultation related to sanctuary zone establishment. Social media provides a medium of communication which allows opinions to reverberate within subpopulations, contributing to the ongoing conflict between sectors who support and oppose sanctuaries (Meyer-McLean \& Nursey-Bray, 2017) and spreading the appearance of widespread opposition across fishing communities. The ability of these highly committed fishers to act as 'opinion 
leaders' (Rogers, 2003) can explain how a small minority of influential opponents can translate into a greater than proportional impact on policy decisions (Gladstone, 2014), despite the support of the majority of fishers (Navarro et al., 2018).

While this research concentrated on sampling the most specialised recreational fishers in Western Australia, there is a significant number of fishers not sampled who have varying level of support for sanctuary zones. Additionally, casual fishers not sampled here may not be actively involved in consultation and may appear as the silent majority in support of sanctuary zones or ambivalent (Stephenson \& Lawson, 2013). However, this may be because casual fishers are more likely to be able to substitute fishing experiences to maintain satisfaction (Oh et al., 2013) and may not be negatively affected by sanctuary zone establishment (McNeill et al., 2018). This does not signify that negative impacts do not occur, instead, it suggests these impacts are concentrated on a specific group of influential specialised fishers. Therefore, the characteristics of recreational fishing subpopulations need to be understood to predict potential impacts of regulations and mitigate negative impacts on fishers, even when those impacted may be in the minority. It is important to note that simplified measurements of the proportion of fishing sites which are still accessible will not appease experiential fishers who rely on specific settings to satisfy their motivations to fish. The conflict surrounding sanctuary zones may also not be diminished by claims of fish stock improvements as compensation, with this argument instead exacerbating the misinformation surrounding the true purpose of sanctuary zones.

To improve support when implementing fishing restrictions, managers would be best to consider not only who may be impacted by changing regulations, but which part of fishing experiences will be affected. This approach would enable managers to design mitigation strategies which maximise fisher satisfaction and ensure appropriate trade-offs are present when fishing freedoms are removed. Multiple use MPAs could be designed to provide diversified or improved fishing experiences aimed at experiential fishers in exchange for creating sanctuary zones. For example, by utilising habitat enhancement or providing fish aggregation devices. Spatial closures could also be designed and implemented permanently or temporally with the explicit aim of increasing large fish, to increase satisfaction amongst experiential fishers who target trophy fish for catch and release. Creating spatial offsets or trade-offs to different segments of recreational fishing communities may strengthen support for an overall management plan which includes contentious sanctuary zones. Engaging specialised fishers early on in the MPA planning process will help build consensus and aid the negotiation of policy aimed at this group, while benefitting planners with the contribution of their extensive knowledge about fish (Voyer et al., 2014). Communication strategies could also be improved by undertaking research and 
considering methods to reduce reactance to policy-related messaging for marine management issues. Examples include consideration of the role of language in message success (Dillard \& Shen, 2005) or the use of narrative-based messaging (Moyer-Gusé \& Nabi, 2010).

Experiential fishers' negative views of the DBCA may represent a significant barrier to engage them in the management of sanctuary zones and improve support for the management strategy. To these fishers, the principles of good governance are lacking - legitimacy, transparency, inclusiveness and fairness (Lockwood et al., 2010) - which are necessary for sanctuary zones to be effective (Bennett \& Dearden, 2014a). Improving perceptions of the management agency may increase trust in the information provided to support the justification of sanctuary zones. Social psychology research demonstrates reactance can be reduced by increasing perceptions of trustworthiness and similarity in values and intentions between message sources and individuals (Silvia, 2005; Song et al., 2018). This may be employed through the recruitment of suitable project partners and ambassadors for the DBCA, for example, recreational fishing identities and organisations. The risk of ignoring reactance encourages boomerang effects where the opposite behaviour is encouraged (Byrne \& Hart, 2009) which threaten the effectiveness of sanctuary zones through illegal fishing.

The results demonstrate experiential fishers consider themselves as supporters of conservation and promote sustainable behaviour (Cooke et al., 2013), although they believe this position is disrespected by conservationists. If fishers feel their interpretation of conservation is not valued by other stakeholders, this may result in perceptions of injustice at the failure of recognition for their alternative understanding (Martin et al., 2013) or dissatisfaction with planning processes which may not sufficiently cater for their worldview (Voyer et al., 2015b). This may also contribute to their rejection of sanctuary zones, as management which excludes recreational fishers is an affront to the way they perceive themselves as active, successful stewards of the marine environment (Meyer-McLean \& Nursey-Bray, 2017). In contrast, fisheries regulations which shape rather than prohibit fishing allows fishers to interact with rules, giving fishers a functional role in management which uses their skills and knowledge. There is an opportunity for this knowledge to be incorporated into marine planning in a partnership capacity to improve collective understanding and build trust with authorities (Young et al., 2016a). Experiential fishers, due to their accumulated knowledge and skills, are ideal candidates to be engaged in management through avenues such as citizen science (Martin et al., 2016b) benefiting the collection of credible, locally relevant data (Gilmour et al., 2015). If trusted evidence can demonstrate the benefits of precautionary sanctuary zones in a particular local area, experiential fishers may be more likely to show their strong support. Recognition of the positive role recreational fishers' can play in 
management will assist in building mutual respect between the fishing and conservation sectors. Improving trust between parties and perceptions of legitimacy will ultimately benefit MPA managers by encouraging community acceptance and support for sanctuary zones, which is essential to achieve long-term success (Bennett, 2016).

\section{CONCLUSION}

This research reveals specialised recreational fishers display the strongest opposition to sanctuary zones while expressing the strongest support for fisheries management regulations. These data indicate the rejection of sanctuaries is in contrast to closures which are temporary or which protect unique and fragile places. Despite the reservations recorded about sanctuary zones, it is promising to note from these results that specialised fishers are strong supporters of regulatory actions aimed at protecting marine resources. This demonstrates that specialised fishers are not averse to respecting spatial closures, or even becoming strong advocates for their appropriate use, but are yet to be convinced of their benefits to marine ecosystems when used in a precautionary manner. These results illustrate that generalised claims of benefits to fish stocks associated with sanctuaries will engender opposition from this sector of the fishing community and should be avoided by policymakers and conservation advocates. This represents a challenge and opportunity for managers to present sanctuary zones in a way which accurately communicates their purpose and promise, and can resonate across the spectrum of interests within recreational fishing communities.

The research also demonstrates that recreational fishers constitute a diverse stakeholder group with contrasting skill levels, priorities and aspirations who value fishing for a broad range of outcomes. A more nuanced understanding of what motivates individuals to take part in fishing will assist policy-makers and managers in designing policy to maximise positive experiences while mitigating adverse effects. Appropriately designed, justified and communicated marine policy will encourage better engagement with the recreational fishing sector and ultimately facilitate improved conservation outcomes.

\section{ACKNOWLEDGEMENTS}

This research was funded by the University of Western Australia. The authors would like to sincerely thank F. Prokop for helpful input. We are grateful to all participants for taking the time to complete the survey and all of the organisations, particularly Recfishwest, who shared the survey with their members 
on our behalf. The first author is grateful for the financial support provided by the Jean Rogerson scholarship trust.

\section{DATA STATEMENT}

Permission to publically share these data were not granted by participants at the time of data collection. The first author can provide additional data and information on request in accordance with human ethics approval and participants permissions. 


\section{REFERENCES}

Anderson, D.K., Ditton, R.B., \& Hunt, K.M. (2007). Measuring Angler Attitudes Toward Catch-Related Aspects of Fishing. Human Dimensions of Wildlife, 12(3), 181-191. doi: 10.1080/10871200701323066

Anderson, M., Gorley, R.N., \& Clarke, R.K. (2008). Permanova+ for Primer: Guide to Software and Statistical Methods. Plymouth, England: Primer-E

Anderson, M.J., \& Willis, T.J. (2003). Canonical analysis of principal coordinates: a useful method of constrained ordination for ecology. Ecology, 84(2), 511-525. doi: 10.1890/00129658(2003)084[0511:Caopca]2.0.Co;2

Arlinghaus, R., Tillner, R., \& Bork, M. (2015). Explaining participation rates in recreational fishing across industrialised countries. Fisheries Management and Ecology, 22(1), 45-55. doi: 10.1111/fme.12075

Bennett, N.J. (2016). Using perceptions as evidence to improve conservation and environmental management. Conservation Biology, 30(3), 582-592. doi: 10.1111/cobi.12681

Bennett, N.J., \& Dearden, P. (2014a). From measuring outcomes to providing inputs: Governance, management, and local development for more effective marine protected areas. Marine Policy, 50, Part A(0), 96-110. doi: 10.1016/j.marpol.2014.05.005

Bennett, N.J., \& Dearden, P. (2014b). Why local people do not support conservation: Community perceptions of marine protected area livelihood impacts, governance and management in Thailand. Marine Policy, 44, 107-116. doi: 10.1016/j.marpol.2013.08.017

Bowling, A. (2005). Mode of questionnaire administration can have serious effects on data quality. Journal of Public Health, 27(3), 281-291. doi: 10.1093/pubmed/fdi031

Brehm, J.W. (1966). A Theory of Psychological Reactance. Oxford, England: Academic Press.

Brehm, S.S., \& Brehm, J.W. (1981). Psychological reactance: A theory of freedom and control. New York, New York: Academic Press.

Bryan, H. (1977). Leisure Value Systems and Recreational Specialization: The Case of Trout Fishermen. Journal of Leisure Research, 9(3), 174. doi: 10.1080/00222216.1977.11970328

Buxton, C.D., \& Cochrane, P. (2015). Commonwealth Marine Reserves Review: Report of the Bioregional Advisory Panel (pp. 341). Canberra, Australia: Department of the Environment.

Byrne, S., \& Hart, P.S. (2009). The Boomerang Effect A Synthesis of Findings and a Preliminary Theoretical Framework. Annals of the International Communication Association, 33(1), 3-37. doi: 10.1080/23808985.2009.11679083

CBD. (2010). Strategic Plan for Biodiversity 2011-2020, Including Aichi Biodiversity Targets. Retrieved 24 October, 2017, from https://www.cbd.int/sp/targets/

Charrad, M., Ghazzali, N., Boiteau, V., \& Niknafs, A. (2014). NbClust: An R Package for Determining the Relevant Number of Clusters in a Data Set. Journal of Statistical Software, 61(6), 1-36. doi: 10.18637/jss.v061.i06

Christie, P. (2004). Marine protected areas as biological successes and social failures in Southeast Asia. American Fisheries Society Symposium, 42, 155-164.

Chuenpagdee, R., Pascual-Fernández, J.J., Szeliánszky, E., Luis Alegret, J., Fraga, J., \& Jentoft, S. (2013). Marine protected areas: Re-thinking their inception. Marine Policy, 39, 234-240. doi: 10.1016/j.marpol.2012.10.016 
Clatworthy, J., Hankins, M., Buick, D., Weinman, J., \& Horne, R. (2007). Cluster analysis in illness perception research: A Monte Carlo study to identify the most appropriate method. Psychology \& Health, 22(2), 123-142. doi: 10.1080/14768320600774496

Cooke, S.J., \& Cowx, I.G. (2004). The Role of Recreational Fishing in Global Fish Crises. Bioscience, 54(9), 857-859. doi: 10.1641/0006-3568(2004)054[0857:TRORFI]2.0.CO;2

Cooke, S.J., Suski, C.D., Arlinghaus, R., \& Danylchuk, A.J. (2013). Voluntary institutions and behaviours as alternatives to formal regulations in recreational fisheries management. Fish and Fisheries, 14(4), 439-457. doi: 10.1111/j.1467-2979.2012.00477.x

Cooke, S.J., Twardek, W.M., Lennox, R.J., Zolderdo, A.J., Bower, S.D., Gutowsky, L.F.G., Danylchuk, A.J., Arlinghaus, R., \& Beard, D. (2018). The nexus of fun and nutrition: Recreational fishing is also about food. Fish and Fisheries, 19(2), 201-224. doi: 10.1111/faf.12246

Dehens, L.A., \& Fanning, L.M. (2018). What counts in making marine protected areas (MPAs) count? The role of legitimacy in MPA success in Canada. Ecological Indicators, 86, 45-57. doi: 10.1016/j.ecolind.2017.12.026

Devillers, R., Pressey, R.L., Grech, A., Kittinger, J.N., Edgar, G.J., Ward, T., \& Watson, R. (2014). Reinventing residual reserves in the sea: are we favouring ease of establishment over need for protection? Aquatic Conservation: Marine and Freshwater Ecosystems, 480-504. doi: 10.1002/aqc. 2445

Dillard, J.P., \& Shen, L. (2005). On the Nature of Reactance and its Role in Persuasive Health Communication. Communication Monographs, 72(2), 144-168. doi: 10.1080/03637750500111815

Ditton, R.B., Loomis, D.K., \& Choi, S. (1992). Recreation Specialization: Re-conceptualization from a Social Worlds Perspective. Journal of Leisure Research, 24(1), 33. doi: 10.1080/00222216.1992.11969870

Dolnicar, S., \& Grün, B. (2008). Challenging "Factor-Cluster Segmentation”. Journal of Travel Research, 47(1), 63-71. doi: 10.1177/0047287508318910

Duda, M.D., \& Nobile, J.L. (2010). The Fallacy of Online Surveys: No Data Are Better Than Bad Data. Human Dimensions of Wildlife, 15(1), 55-64. doi: 10.1080/10871200903244250

Freudenberg, P., \& Arlinghaus, R. (2009). Benefits and Constraints of Outdoor Recreation for People with Physical Disabilities: Inferences from Recreational Fishing. Leisure Sciences, 32(1), 55-71. doi: 10.1080/01490400903430889

Garlock, T.M., \& Lorenzen, K. (2017). Marine angler characteristics and attitudes toward stock enhancement in Florida. Fisheries Research, 186, 439-445. doi: 10.1016/j.fishres.2016.08.017

Gilmour, P., Coffey, B., \& O'Toole, K. (2015). Trust and knowledge exchange in coastal settings. Australian Journal of Maritime \& Ocean Affairs, 7(1), 66-74. doi: 10.1080/18366503.2015.1014013

Gladstone, W. (2014). Criticisms of science, social impacts, opinion leaders, and targets for no-take zones led to cuts in New South Wales' (Australia) system of marine protected areas. Aquatic Conservation: Marine and Freshwater Ecosystems, 24(3), 287-296. doi: 10.1002/aqc.2469

Graefe, A., Mowen, A., Covelli, E., \& Trauntvein, N. (2011). Recreation Participation and Conservation Attitudes: Differences Between Mail and Online Respondents in a Mixed-Mode Survey. Human Dimensions of Wildlife, 16(3), 183-199. doi: 10.1080/10871209.2011.571750

Granek, E.F., Madin, E.M.P., Brown, M.A., Figueira, W., Cameron, D.S., Hogan, Z., Kristianson, G., De Villiers, P., Williams, J.E., Post, J., Zahn, S., \& Arlinghaus, R. (2008). Engaging Recreational Fishers in Management and Conservation: Global Case Studies. Conservation Biology, 22(5), 1125-1134. doi: 10.1111/j.1523-1739.2008.00977.x 
Griffiths, S.P., Bryant, J., Raymond, H.F., \& Newcombe, P.A. (2017). Quantifying subjective human dimensions of recreational fishing: does good health come to those who bait? Fish and Fisheries, 18(1), 171-184. doi: 10.1111/faf.12149

Halpern, B.S., Walbridge, S., Selkoe, K.A., Kappel, C.V., Micheli, F., D'Agrosa, C., Bruno, J.F., Casey, K.S., Ebert, C., Fox, H.E., Fujita, R., Heinemann, D., Lenihan, H.S., Madin, E.M.P., Perry, M.T., Selig, E.R., Spalding, M., Steneck, R., \& Watson, R. (2008). A Global Map of Human Impact on Marine Ecosystems. Science, 319(5865), 948-952. doi: 10.1126/science.1149345

Hatcher, A., Jaffry, S., Thebaud, O., \& Bennett, E. (2000). Normative and social influences affecting compliance with fishery regulations. Land Economics, 76(3), 448-461. doi: 10.2307/3147040

Henry, G.W., \& Lyle, J.M. (2003). The National Recreational and Indigenous Fishing Survey NSW Fisheries final report series; no. 48. Sydney, Australia: NSW Fisheries.

Herfaut, J., Levrel, H., Thébaud, O., \& Véron, G. (2013). The nationwide assessment of marine recreational fishing: A French example. Ocean \& Coastal Management, 78, 121-131. doi: 10.1016/j.ocecoaman.2013.02.026

Hilborn, R., Stokes, K., Maguire, J.J., Smith, T., Botsford, L.W., Mangel, M., Orensanz, J., Parma, A., Rice, J., Bell, J., Cochrane, K.L., Garcia, S., Hall, S.J., Kirkwood, G.P., Sainsbury, K., Stefansson, G., \& Walters, C. (2004). When can marine reserves improve fisheries management? Ocean and Coastal Management, 47(3-4), 197-205. doi: 10.1016/j.ocecoaman.2004.04.001

Hyman, A.A., DiCenzo, V.J., \& Murphy, B.R. (2017). Muddling management: heterogeneity of blue catfish anglers. Lake and Reservoir Management, 33(1), 23-31. doi: 10.1080/10402381.2016.1261310

IUCN. (2016). IUCN Resolutions, Recommendations and other Decisions Gland, Switzerland: IUCN.

Jones, P.J.S. (2007). Point-of-View: Arguments for conventional fisheries management and against notake marine protected areas: only half of the story? Reviews in Fish Biology and Fisheries, 17(1), 31-43. doi: 10.1007/s11160-006-9016-8

Kaufman, L., \& Rousseeuw, P.J. (2009). Finding Groups in Data: An Introduction to Cluster Analysis. Hoboken, New Jersey: John Wiley \& Sons.

Kearney, R., Buxton, C.D., \& Farebrother, G. (2012). Australia's no-take marine protected areas: Appropriate conservation or inappropriate management of fishing? Marine Policy, 36(5), 10641071. doi: 10.1016/j.marpol.2012.02.024

Kyle, G., Norman, W., Jodice, L., Graefe, A., \& Marsinko, A. (2007). Segmenting Anglers Using Their Consumptive Orientation Profiles. Human Dimensions of Wildlife, 12(2), 115-132. doi: 10.1080/10871200701196066

Lester, S.E., Halpern, B.S., Grorud-Colvert, K., Lubchenco, J., Ruttenberg, B.I., Gaines, S.D., Airame, S., \& Warner, R.R. (2009). Biological effects within no-take marine reserves: a global synthesis. Marine Ecology Progress Series, 384, 33-46. doi: 10.3354/meps08029

Lewin, W.C., Arlinghaus, R., \& Mehner, T. (2006). Documented and potential biological impacts of recreational fishing: Insights for management and conservation. Reviews in Fisheries Science, 14(4), 305-367. doi: 10.1080/10641260600886455

Lockwood, M., Davidson, J., Curtis, A., Stratford, E., \& Griffith, R. (2010). Governance Principles for Natural Resource Management. Society \& Natural Resources, 23(10), 986-1001. doi: 10.1080/08941920802178214

Magee, C., Voyer, M., McIlgorm, A., \& Li, O. (2018). Chasing the thrill or just passing the time? Trialing a new mixed methods approach to understanding heterogeneity amongst recreational fishers based on motivations. Fisheries Research, 199, 107-118. doi: 10.1016/j.fishres.2017.11.026

Martin, A., McGuire, S., \& Sullivan, S. (2013). Global environmental justice and biodiversity conservation. The Geographical Journal, 179(2), 122-131. doi: 10.1111/geoj.12018 
Martin, C.L., Momtaz, S., Jordan, A., \& Moltschaniwskyj, N.A. (2016a). Exploring recreational fishers' perceptions, attitudes, and support towards a multiple-use marine protected area six years after implementation. Marine Policy, 73, 138-145. doi: 10.1016/j.marpol.2016.08.002

Martin, V., Smith, L., Bowling, A., Christidis, L., Lloyd, D., \& Pecl, G. (2016b). Citizens as Scientists: What Influences Public Contributions to Marine Research? Science Communication, 38(4), 495-522. doi: $10.1177 / 1075547016656191$

Mascia, M.B., Claus, C.A., \& Naidoo, R. (2010). Impacts of Marine Protected Areas on Fishing Communities. Conservation Biology, 24(5), 1424-1429. doi: 10.1111/j.1523-1739.2010.01523.x

McClenachan, L. (2013). Recreation and the "Right to Fish" Movement: Anglers and Ecological Degradation in the Florida Keys. Environmental History, 18(1), 76-87. doi: 10.1093/envhis/ems110

McNeill, A., Clifton, J., \& Harvey, E.S. (2018). Attitudes to a marine protected area are associated with perceived social impacts. Marine Policy, 94, 106-118. doi: 10.1016/j.marpol.2018.04.020

Meyer-McLean, C.B., \& Nursey-Bray, M. (2017). Getting off the conflict treadmill: community engagement and marine park policy in South Australia, Australia. Australian Journal of Maritime \& Ocean Affairs, 1-25. doi: 10.1080/18366503.2017.1332475

Milligan, G.W. (1980). An examination of the effect of six types of error perturbation on fifteen clustering algorithms. Psychometrika, 45(3), 325-342. doi: 10.1007/BF02293907

Milligan, G.W., \& Cooper, M.C. (1988). A study of standardization of variables in cluster analysis. Journal of Classification, 5(2), 181-204. doi: 10.1007/bf01897163

Moyer-Gusé, E., \& Nabi, R.L. (2010). Explaining the Effects of Narrative in an Entertainment Television Program: Overcoming Resistance to Persuasion. Human Communication Research, 36(1), 26-52. doi: 10.1111/j.1468-2958.2009.01367.x

Navarro, M., Kragt, M.E., Hailu, A., \& Langlois, T.J. (2018). Recreational fishers' support for no-take marine reserves is high and increases with reserve age. Marine Policy, 96, 44-52. doi: 10.1016/j.marpol.2018.06.021

Oh, C.-O., Sutton, S.G., \& Sorice, M.G. (2013). Assessing the Role of Recreation Specialization in Fishing Site Substitution. Leisure Sciences, 35(3), 256-272. doi: 10.1080/01490400.2013.780534

Ordoñez-Gauger, L., Richmond, L., Hackett, S., \& Chen, C. (2018). It's a trust thing: Assessing fishermen's perceptions of the California North Coast marine protected area network. Ocean \& Coastal Management, 158, 144-153. doi: 10.1016/j.ocecoaman.2018.03.034

Palmer, L. (2004). Fishing Lifestyles: 'Territorians', Traditional Owners and the Management of Recreational Fishing in Kakadu National Park. Australian Geographical Studies, 42(1), 60-76. doi: 10.1111/j.1467-8470.2004.00243.x

Penn, J.W., \& Fletcher, W.J. (2010). The efficacy of sanctuary areas for the management of fish stocks and biodiversity in WA waters Fisheries Research Report No. 169. Perth, Western Australia: Department of Fisheries.

Pollnac, R.B., Crawford, B.R., \& Gorospe, M.L.G. (2001). Discovering factors that influence the success of community-based marine protected areas in the Visayas, Philippines. Ocean \& Coastal Management, 44(11-12), 683-710. doi: 10.1016/S0964-5691(01)00075-8

Punj, G., \& Stewart, D.W. (1983). Cluster Analysis in Marketing Research: Review and Suggestions for Application. Journal of Marketing Research, 20(2), 134-148. doi: 10.2307/3151680

Rains, S.A. (2013). The nature of psychological reactance revisited: A meta-analytic review. Human Communication Research, 39(1), 47-73. doi: 10.1111/j.1468-2958.2012.01443.x

Rogers, E.M. (2003). Diffusion of innovations (5th ed.). New York, New York: Free Press. 
Ryan, K.L., Hall, N.G., Lai, E.K., Smallwood, C.B., Taylor, S.M., \& Wise, B.S. (2015). State-wide survey of boat-based recreational fishing in Western Australia 2013/14 Fisheries Research Report No. 268. Perth, Western Australia: Department of Fisheries.

Salvador, S., \& Chan, P. (2004). Determining the number of clusters/segments in hierarchical clustering/segmentation algorithms. Paper presented at the 16th IEEE International Conference on Tools with Artificial Intelligence, Boca Raton, Florida. 10.1109/ICTAI.2004.50

Salz, R.J., \& Loomis, D.K. (2004). Saltwater Anglers' Attitudes towards Marine Protected Areas. Fisheries, 29(6), 10-17. doi: 10.1577/1548-8446(2004)29[10:SAATMP]2.0.CO;2

Salz, R.J., \& Loomis, D.K. (2005). Recreation Specialization and Anglers' Attitudes Towards Restricted Fishing Areas. Human Dimensions of Wildlife, 10(3), 187-199. doi: 10.1080/10871200591003436

Salz, R.J., Loomis, D.K., \& Finn, K.L. (2001). Development and Validation of a Specialization Index and Testing of Specialization Theory. Human Dimensions of Wildlife, 6(4), 239-258. doi: 10.1080/108712001753473939

Scott, D., \& Shafer, C.S. (2001). Recreational Specialization: A Critical Look at the Construct. Journal of Leisure Research, 33(3), 319-343. doi: 10.1080/00222216.2001.11949944

Sheridan, P. (2016). False polemics or real consensus? What Australians really think about marine protected areas. In J. Fitzsimons \& G. Wescott (Eds.), Big, Bold and Blue: Lessons from Australia's Marine Protected Areas. Melbourne, Australia: CSIRO Publishing.

Siegel, S., \& Castellan, N.J. (1988). Nonparametric statistics for the behavioral sciences (2nd ed.). New York, New York: McGraw-Hill.

Silvia, P.J. (2005). Deflecting Reactance: The Role of Similarity in Increasing Compliance and Reducing Resistance. Basic and Applied Social Psychology, 27(3), 277-284. doi: 10.1207/s15324834basp2703_9

Song, H., McComas, K.A., \& Schuler, K.L. (2018). Source Effects on Psychological Reactance to Regulatory Policies: The Role of Trust and Similarity. Science Communication, 40(5), 591-620. doi: $10.1177 / 1075547018791293$

Stephenson, J., \& Lawson, R. (2013). Giving voice to the 'silent majority': exploring the opinions and motivations of people who do not make submissions. Policy Quarterly, 9(1), 26-33.

Sutton, S.G. (2003). Personal and Situational Determinants of Catch-and-Release Choice of Freshwater Anglers. Human Dimensions of Wildlife, 8(2), 109-126. doi: 10.1080/10871200304300

Sutton, S.G. (2006). Understanding Recreational Fishers' Participation in Public Consultation Programs. Human Dimensions of Wildlife, 11(5), 329-341. doi: 10.1080/10871200600894969

Sutton, S.G., \& Oh, C.O. (2015). How Do Recreationists Make Activity Substitution Decisions? A Case of Recreational Fishing. Leisure Sciences, 37(4), 332-353. doi: 10.1080/01490400.2015.1016195

Turner, R.A., Addison, J., Arias, A., Bergseth, B.J., Marshall, N.A., Morrison, T.H., \& Tobin, R.C. (2016). Trust, confidence, and equity affect the legitimacy of natural resource governance. Ecology and Society, 21(3). doi: 10.5751/ES-08542-210318

Viteri, C., \& Chávez, C. (2007). Legitimacy, local participation, and compliance in the Galápagos Marine Reserve. Ocean \& Coastal Management, 50(3), 253-274. doi: 10.1016/j.ocecoaman.2006.05.002

Voyer, M., Dreher, T., Gladstone, W., \& Goodall, H. (2013). Dodgy science or global necessity? Local media reporting of marine parks. In L. Lester \& B. Hutchins (Eds.), Environmental Conflict and the Media. New York, New York: Peter Lang Publishing.

Voyer, M., Gladstone, W., \& Goodall, H. (2014). Understanding marine park opposition: the relationship between social impacts, environmental knowledge and motivation to fish. Aquatic Conservation: Marine and Freshwater Ecosystems, 24(4), 441-462. doi: 10.1002/aqc.2363 
Voyer, M., Gladstone, W., \& Goodall, H. (2015a). Obtaining a social licence for MPAs - influences on social acceptability. Marine Policy, 51, 260-266. doi: 10.1016/j.marpol.2014.09.004

Voyer, M., Gollan, N., Barclay, K., \& Gladstone, W. (2015b). 'It's part of me'; understanding the values, images and principles of coastal users and their influence on the social acceptability of MPAs. Marine Policy, 52(0), 93-102. doi: 10.1016/j.marpol.2014.10.027

Wallen, K.E., Landon, A.C., Kyle, G.T., Schuett, M.A., Leitz, J., \& Kurzawski, K. (2016). Mode Effect and Response Rate Issues in Mixed-Mode Survey Research: Implications for Recreational Fisheries Management. North American Journal of Fisheries Management, 36(4), 852-863. doi: 10.1080/02755947.2016.1165764

Young, J.C., Searle, K., Butler, A., Simmons, P., Watt, A.D., \& Jordan, A. (2016a). The role of trust in the resolution of conservation conflicts. Biological Conservation, 195, 196-202. doi: 10.1016/j.biocon.2015.12.030

Young, M.A.L., Foale, S., \& Bellwood, D.R. (2016b). Why do fishers fish? A cross-cultural examination of the motivations for fishing. Marine Policy, 66, 114-123. doi: 10.1016/j.marpol.2016.01.018 


\section{SUPPLEMENTARY MATERIALS}

Table S1. Full list of survey topics and items used to measure avidity and catch motivations.

\begin{tabular}{|c|c|c|}
\hline Category: Question & Item & Measurement \\
\hline \multirow[t]{4}{*}{ Avidity } & $\begin{array}{l}\text { For how many years have you been fishing } \\
\text { recreationally? If you have started fishing in the last } 12 \\
\text { months please answer ' } 1 \text { '. }\end{array}$ & Whole number \\
\hline & $\begin{array}{l}\text { Approximately how many days have you gone fishing in } \\
\text { WA in the last } 12 \text { months? }\end{array}$ & Whole number \\
\hline & $\begin{array}{l}\text { How would you compare fishing to other outdoor } \\
\text { recreation activities you take part in? }\end{array}$ & $\begin{array}{l}\text { Fishing is your most important outdoor } \\
\text { activity, } \\
\text { Fishing is your second most important } \\
\text { outdoor activity, } \\
\text { Fishing is your third most important } \\
\text { outdoor activity, } \\
\text { Fishing is one of many outdoor } \\
\text { activities you take part in. }\end{array}$ \\
\hline & $\begin{array}{l}\text { How would you rate your ability as a fisher compared to } \\
\text { others? }\end{array}$ & $\begin{array}{l}\text { Beginner, } \\
\text { Intermediate, } \\
\text { Advanced, } \\
\text { Expert. }\end{array}$ \\
\hline \multirow{14}{*}{$\begin{array}{l}\text { Non-catch } \\
\text { motivations: "Why } \\
\text { do you go fishing? } \\
\text { Please rate the } \\
\text { importance of the } \\
\text { following reasons" }\end{array}$} & To improve my skill/knowledge of fishing & \multirow{14}{*}{$\begin{array}{l}\text { Not at all important, } \\
\text { Slightly important, } \\
\text { Moderately important, } \\
\text { Very important, } \\
\text { Extremely important, } \\
\text { Don't know. }\end{array}$} \\
\hline & To test my equipment & \\
\hline & To experience new and different things & \\
\hline & For the challenge of the sport of catching fish & \\
\hline & For the fun of an exciting fight with fish & \\
\hline & To be close to the water & \\
\hline & To spend time outdoors & \\
\hline & For relaxation & \\
\hline & To escape from everyday life, work or the city & \\
\hline & To experience the natural environment & \\
\hline & To enjoy solitude and time for myself & \\
\hline & $\begin{array}{l}\text { For the social experience with family, quality time } \\
\text { together }\end{array}$ & \\
\hline & For the social experiences with friends & \\
\hline & As a traditional indigenous Australian cultural practice & \\
\hline \multirow{12}{*}{$\begin{array}{l}\text { Catch motivations: } \\
\text { "To what extent do } \\
\text { you agree with the } \\
\text { following } \\
\text { statements about } \\
\text { catching fish?" }\end{array}$} & $\begin{array}{l}\text { A fishing trip can be successful even if no fish are caught } \\
\text { (REVERSE CODED) }\end{array}$ & \multirow{12}{*}{$\begin{array}{l}\text { Strongly agree, } \\
\text { Somewhat agree, } \\
\text { Neutral, } \\
\text { Somewhat disagree, } \\
\text { Strongly disagree, } \\
\text { Don't know. }\end{array}$} \\
\hline & $\begin{array}{l}\text { If I thought I wouldn't catch any fish, I wouldn't go } \\
\text { fishing }\end{array}$ & \\
\hline & $\begin{array}{l}\text { When I go fishing, I'm not satisfied unless I catch } \\
\text { something }\end{array}$ & \\
\hline & The more fish I catch, the better the fishing trip & \\
\hline & $\begin{array}{l}\text { I'm happiest with a fishing trip if I catch the daily bag } \\
\text { limit of fish }\end{array}$ & \\
\hline & $\begin{array}{l}\text { A successful fishing trip is one in which many fish are } \\
\text { caught }\end{array}$ & \\
\hline & $\begin{array}{l}\text { I would rather catch one or two big fish than ten smaller } \\
\text { fish }\end{array}$ & \\
\hline & $\begin{array}{l}\text { I'm happiest with a fishing trip if I catch a challenging } \\
\text { game fish }\end{array}$ & \\
\hline & $\begin{array}{l}\text { I like to fish where I have a chance to catch a really big } \\
\text { fish }\end{array}$ & \\
\hline & I usually eat the fish I catch & \\
\hline & $\begin{array}{l}\text { I'm just as happy if I don't keep any of the fish I catch } \\
\text { (REVERSE CODED) }\end{array}$ & \\
\hline & $\begin{array}{l}\text { I'm just as happy if I release fish that I could keep } \\
\text { (REVERSE CODED) }\end{array}$ & \\
\hline
\end{tabular}


Table S2. Full list of survey topics and items used to explore fishers' opinions of management and management issues.

\begin{tabular}{|c|c|c|}
\hline Question & $\begin{array}{l}\text { Western Australian state regulations relating to } \\
\text { recreational fisheries }\end{array}$ & Measurement \\
\hline \multirow{6}{*}{$\begin{array}{l}\text { Within the bioregion } \\
\text { you stated you fish } \\
\text { most often, how } \\
\text { supportive are you of } \\
\text { the following } \\
\text { recreational fishing } \\
\text { regulations? }\end{array}$} & Catch limits e.g. bag and boat limits & \multirow{10}{*}{$\begin{array}{l}\text { Strongly in favour, Somewhat in favour, } \\
\text { Neutral, } \\
\text { Somewhat oppose, } \\
\text { Strongly oppose, } \\
\text { Don't know. }\end{array}$} \\
\hline & $\begin{array}{l}\text { Gear restrictions e.g. number of hooks or use of } \\
\text { spear guns }\end{array}$ & \\
\hline & Possession limits & \\
\hline & Size limits - maximum sizes and slot limits & \\
\hline & Size limits - minimum sizes & \\
\hline & No take rules for protected species \& breeding fish & \\
\hline \multirow{4}{*}{$\begin{array}{l}\text { If you are unfamiliar } \\
\text { with any of these } \\
\text { regulations simply } \\
\text { select "don't know" }\end{array}$} & $\begin{array}{l}\text { Closed fishing seasons e.g. the West Coast region } \\
\text { demersal ban }\end{array}$ & \\
\hline & $\begin{array}{l}\text { Certain areas closed to fishing for a specific event } \\
\text { e.g. Pink Snapper spawning }\end{array}$ & \\
\hline & $\begin{array}{l}\text { Certain areas closed to fishing to protect a unique } \\
\text { or fragile place e.g. Hamelin Pool Reserve }\end{array}$ & \\
\hline & $\begin{array}{l}\text { Certain areas permanently closed to all fishing } \\
\text { activities e.g. no fishing zones or sanctuary zones }\end{array}$ & \\
\hline Question & $\begin{array}{l}\text { Belief statements to measure views on fishing } \\
\text { management }\end{array}$ & Measurement \\
\hline \multirow{9}{*}{$\begin{array}{l}\text { To what extent do } \\
\text { you agree with the } \\
\text { following statements } \\
\text { about managing the } \\
\text { marine environment? }\end{array}$} & $\begin{array}{l}\text { Closing some areas to fishing permanently can } \\
\text { damage other open areas due to crowding of } \\
\text { fishing pressure }\end{array}$ & \multirow{9}{*}{$\begin{array}{l}\text { Strongly agree, } \\
\text { Somewhat agree, } \\
\text { Neither agree nor disagree, } \\
\text { Somewhat disagree, } \\
\text { Strongly disagree, } \\
\text { Don't know. }\end{array}$} \\
\hline & $\begin{array}{l}\text { There is no scientific evidence to justify locking out } \\
\text { recreational fishers from large areas of our seas }\end{array}$ & \\
\hline & $\begin{array}{l}\text { Recfishers are unfairly portrayed by } \\
\text { conservationists as damaging the marine } \\
\text { environment }\end{array}$ & \\
\hline & $\begin{array}{l}\text { I'm willing to change my fishing habits to ensure } \\
\text { there is healthy fishing for future generations }\end{array}$ & \\
\hline & $\begin{array}{l}\text { Closing some areas to fishing permanently is a } \\
\text { good safeguard to help conserve marine } \\
\text { ecosystems in the future }\end{array}$ & \\
\hline & $\begin{array}{l}\text { Recreational fishing is not a threat to healthy } \\
\text { marine ecosystems }\end{array}$ & \\
\hline & $\begin{array}{l}\text { The combined impact of thousands of recfishers } \\
\text { can result in damage to the marine environment }\end{array}$ & \\
\hline & $\begin{array}{l}\text { Closing some areas to fishing permanently can } \\
\text { help protect important areas like fish nurseries }\end{array}$ & \\
\hline & $\begin{array}{l}\text { Areas closed to fishing won't protect fish because } \\
\text { there are no fences around protected areas to } \\
\text { keep them inside }\end{array}$ & \\
\hline \multicolumn{3}{|c|}{$\begin{array}{l}\text { There are two different Western Australian State Government agencies which are responsible for managing } \\
\text { recreational fishing activities in our local waters - the Department of Fisheries and the Department of Parks and } \\
\text { Wildlife, previously known as CALM or DEC. }\end{array}$} \\
\hline Question & $\begin{array}{l}\text { Are you aware of these two different government } \\
\text { agencies? }\end{array}$ & $\begin{array}{l}\text { Yes or No. (No answers screen out } \\
\text { respondents and end survey). }\end{array}$ \\
\hline \multicolumn{3}{|c|}{$\begin{array}{l}\text { First we will ask you about the Department of Fisheries, the state government agency in charge of fishing rules and } \\
\text { regulations in WA. }\end{array}$} \\
\hline Question & $\begin{array}{l}\text { Belief statements to measure views on } \\
\text { management authorities }\end{array}$ & Measurement \\
\hline \multirow{4}{*}{$\begin{array}{l}\text { To what extent do } \\
\text { you agree with the } \\
\text { following statements } \\
\text { about the } \\
\text { Department? If you } \\
\text { haven't had enough } \\
\text { experience with them } \\
\text { to answer the }\end{array}$} & $\begin{array}{l}\text { Recfishers have been given the opportunity to } \\
\text { have their say on fishing rules in WA }\end{array}$ & \multirow{4}{*}{$\begin{array}{l}\text { Strongly agree, } \\
\text { Somewhat agree, } \\
\text { Neither agree nor disagree, } \\
\text { Somewhat disagree, } \\
\text { Strongly disagree, } \\
\text { Don't know. }\end{array}$} \\
\hline & $\begin{array}{l}\text { The input of recfishers has no influence on WA } \\
\text { fishing policy decisions }\end{array}$ & \\
\hline & $\begin{array}{l}\text { Fisheries makes unbiased policy decisions based on } \\
\text { fact }\end{array}$ & \\
\hline & $\begin{array}{l}\text { Fisheries don't treat recfishers in a fair and } \\
\text { reasonable way }\end{array}$ & \\
\hline
\end{tabular}




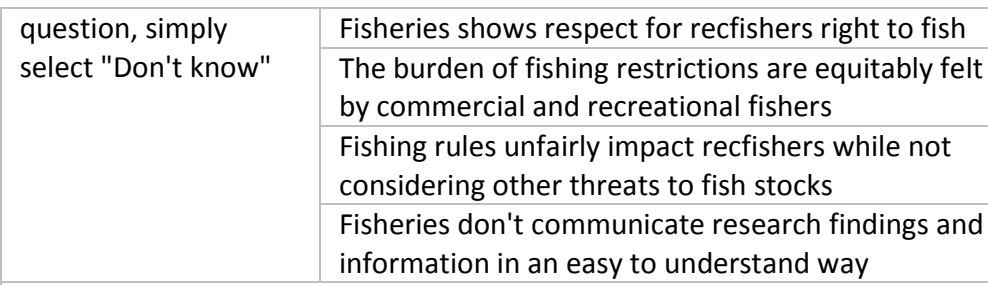

Now we are going to ask you about the Department of Parks and Wildlife (DPaW), the state government agency in charge of Marine Parks and reserves in WA which contain areas closed to fishing, as well as areas with use restrictions.

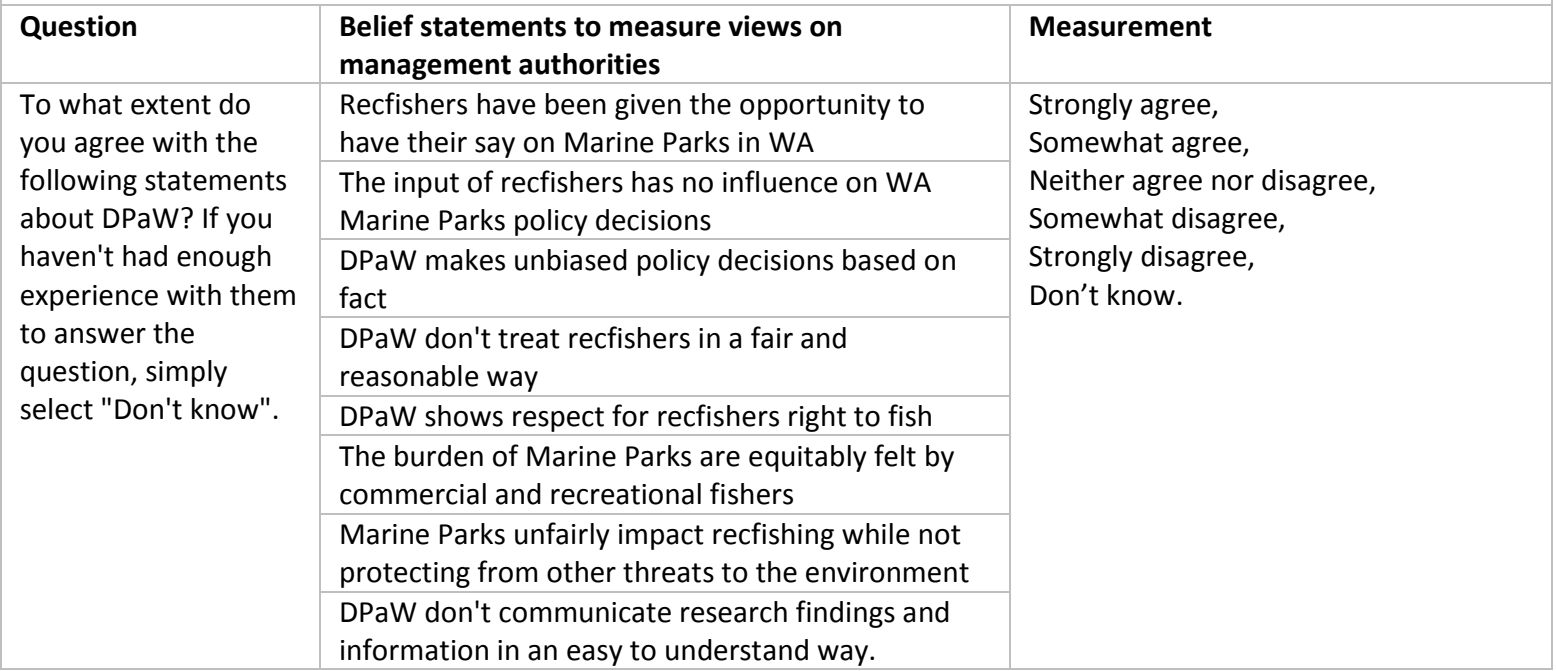

Note, since the survey was conducted, the Department of Parks and Wildlife has been renamed the Department of Biodiversity, Conservation and Attractions (DBCA), and the Department of Fisheries has merged and renamed the Department of Primary Industries and Regional Development (DPIRD). 